\title{
Long-term volcanic hazard assessment on EI Hierro (Canary Islands)
}

\author{
L. Becerrii ${ }^{1}$, S. Bartolini ${ }^{1}$, R. Sobradelo ${ }^{1}$, J. Martí ${ }^{1}$, J. M. Morales ${ }^{2}$, and I. Galindo ${ }^{2}$ \\ ${ }^{1}$ Institute of Earth Sciences Jaume Almera, ICTJA-CSIC, Group of Volcanology, SIMGEO (UB-CSIC) Lluis Sole i Sabaris \\ s/n, 08028 Barcelona, Spain \\ ${ }^{2}$ Instituto Geológico y Minero de España (IGME) c/Alonso Alvarado, 43-2A, 35003 Las Palmas de Gran Canaria, Spain
}

Correspondence to: L. Becerril (laurabcar@gmail.com)

Received: 22 January 2014 - Published in Nat. Hazards Earth Syst. Sci. Discuss.: 24 February 2014

Revised: 10 June 2014 - Accepted: 13 June 2014 - Published: 28 July 2014

\begin{abstract}
Long-term hazard assessment, one of the bastions of risk-mitigation programs, is required for land-use planning and for developing emergency plans. To ensure quality and representative results, long-term volcanic hazard assessment requires several sequential steps to be completed, which include the compilation of geological and volcanological information, the characterisation of past eruptions, spatial and temporal probabilistic studies, and the simulation of different eruptive scenarios. Despite being a densely populated active volcanic region that receives millions of visitors per year, no systematic hazard assessment has ever been conducted on the Canary Islands. In this paper we focus our attention on El Hierro, the youngest of the Canary Islands and the most recently affected by an eruption. We analyse the past eruptive activity to determine the spatial and temporal probability, and likely style of a future eruption on the island, i.e. the where, when and how. By studying the past eruptive behaviour of the island and assuming that future eruptive patterns will be similar, we aim to identify the most likely volcanic scenarios and corresponding hazards, which include lava flows, pyroclastic fallout and pyroclastic density currents (PDCs). Finally, we estimate their probability of occurrence. The end result, through the combination of the most probable scenarios (lava flows, pyroclastic density currents and ashfall), is the first qualitative integrated volcanic hazard map of the island.
\end{abstract}

\section{Introduction}

The possibility of future eruptive activity, coupled with population growth and economic and cultural development in the majority of active volcanic areas, means that mitigative measures against volcanic risk, such as the development of volcanic hazard analyses, must be undertaken. These types of analyses are a fundamental part of risk management tasks that include the developing of volcanic hazard maps, landuse planning and emergency plans.

The volcanic hazard of a given area is the probability that it will be affected by a process of a certain volcanic magnitude within a specific time interval (Fournier d'Albe, 1979). Therefore, volcanic hazard assessment must necessarily be based on good knowledge of the past eruptive history of the volcanic area, which will tell us "how" eruptions have occurred. It also requires the spatial probability of occurrence of a hazard to be determined; i.e. "where" the next eruption can take place (volcanic susceptibility) and its extent, as well as its temporal probability, in other words "when" the next eruption may occur in the near future.

The complexity of any volcanic system and its associated eruptive processes, together with the lack of data that is typical of so many active volcanoes and volcanic areas (and in particular those with long periods between eruptions), make volcanic hazard quantification a challenge. Long-term hazard assessment is necessary to know how the next eruption could be. It is based on the past history of the volcano and the information needed comes from the geological record. Unlike short-term assessment that evaluates hazards from days to a few months, using data provided by monitoring networks, 
long-term assessment is estimated from years to decades, where the main source of information is mainly structural data from past eruptions (Marzocchi et al., 2006). Different steps need to be followed sequentially in any long-term volcanic hazard assessment. The first step consists of evaluating the likelihood of a future eruption, which will provide an indication of which areas are most likely to host future vents (Martí and Felpeto, 2010). The long-term spatial probability of vent opening can be estimated using structural data such as vents, dykes, faults, fractures and eruptive fissure-alignments obtained from geological and geophysical studies. These data can be converted into Probability Density Functions (PDFs) and then combined to obtain the final susceptibility map (Martin et al., 2004; Felpeto et al., 2007; Connor and Connor, 2009; Martí and Felpeto, 2010; Cappello et al., 2012; Bartolini et al., 2013; Becerril et al., 2013). Susceptibility maps show the spatial probability of hosting new future eruptions. This term has been commonly used during the last years by other authors in the volcanic field (Felpeto et al., 2007; Cappello et al., 2010, 2011, 2012; Martí and Felpeto, 2010; Vicari et al., 2011; Alcorn et al., 2013; Bartolini et al., 2013; Becerril et al., 2013).

The next step corresponds to the temporal probability estimation of any possible volcanic event. Long-term forecasting is based on historical and geological data, as well as on theoretical models, and refers to the time window available before an unrest episode occurs in the volcanic system. In this regard, some authors use probabilistic statistical methods based on the Bayesian event tree for long-term volcanic hazard assessment (Newhall and Hoblitt, 2002; Marzocchi et al., 2008; Sobradelo and Martí, 2010), while some others use a deterministic approach (Voight and Cornelius, 1991; Kilburn, 2003; see also Hill et al., 2001).

Once spatial and temporal probabilities have been estimated, the next step forward consists of computing several scenarios as a means of evaluating the potential extent of the main expected volcanic and associated hazards. Most of these studies are based on the use of simulation models and Geographical Information Systems (GIS) that allow volcanic hazards such as lava flows, PDCs and ash fallout to be modelled and visualised (Pareschi et al., 2000; Felpeto et al., 2007; Toyos et al., 2007; Crisci et al., 2008; Cappello et al., 2012; Martí et al., 2012; Alcorn et al., 2013).

All of these steps should be undertaken to evaluate the potential volcanic hazards of any active volcanic area. Similar approaches have been applied in volcanic areas such as Auckland, New Zealand (Bebbington and Cronin, 2011); Etna, Sicily (Cappello et al., 2013); and Tenerife, Spain (Martí et al., 2012); Perú (Sandri et al., 2014). Nevertheless, other procedures have also been applied in order to assess volcanic hazards in Campi Flegrei, Italy (Lirer et al., 2001); Furnas (São Miguel, Azores) Vesuvius in Italy (Chester et al., 2002); and Auckland, New Zealand (Sandri et al., 2012). Compared with these previous approaches, our study offers a procedure that facilitates undertaking volcanic hazard assessment in a systematic way, which can be easily applied to other volcanic areas around the world.

The Canary Islands are the only area of Spain in which volcanic activity has occurred in the last 600 years, representing one of the world's largest oceanic volcanic zones. The geodynamic environment in which the archipelago lies and the characteristics of its recent and historical volcanism suggest that the volcanic activity that has characterised this archipelago for more than $60 \mathrm{Ma}$ will continue in the future. Previous volcanic hazard studies conducted on the Canary Islands have not followed a systematic method. Most work to date has focused on Tenerife and Lanzarote (GómezFernández, 1996; Araña et al., 2000; Felpeto et al., 2001, 2007; Felpeto, 2002; Carracedo et al., 2004a, b, 2005; Martí and Felpeto, 2010; Sobradelo and Martí, 2010; Martí et al., 2012; Bartolini et al., 2013), although other studies have been carried out on Gran Canaria (Rodríguez-González, 2009), El Hierro (Becerril et al., 2013) and one for the Canary Islands as a whole (Sobradelo et al., 2011).

In this study we focus on El Hierro and conduct a longterm volcanic hazard assessment by taking into account spatial and temporal probabilities. Despite being small and submarine in nature (Martí et al., 2013), the most recent eruption on El Hierro (October 2011-February 2012) highlighted the need for volcanic hazard studies, given the negative impact on tourism and the local economy of any volcanic event. Although this eruption was not different in terms of magma volume and volcanic products from most eruptions that historically occurred in the Canarian Archipelago, this eruption marked the end of a 40-year period of quiescence in this volcanic region. El Hierro has a population of 10960 inhabitants (www.ine.es), or $0.51 \%$ of the total population of the Canary Islands. Its main economic resources are tourism and fishery, two aspects that may be - and in fact were - seriously affected by the impact of volcanic activity.

In this work we present a systematic analysis of the volcanic hazards present on this island that includes the following steps: (1) characterisation of past volcanism in the study area; (2) estimation of spatio-temporal probabilities; (3) simulation of the most probable eruptive scenarios such as lava flows, pyroclastic fallout and pyroclastic density currents (PDCs); and (4) assessment of the volcanic hazard.

\section{Geological setting}

The Canary Islands extend for roughly $500 \mathrm{~km}$ in a chain that has developed on the passive margin of the African plate in the eastern central Atlantic Ocean (Fig. 1, inset). The Canarian Archipelago is the result of long-term volcanic and tectonic activity that started around $60 \mathrm{Ma}$ (Robertson and Stillman, 1979; Le Bas et al., 1986; Araña and Ortiz, 1991; Marinoni and Pasquaré, 1994). A number of contrasting models - including the presence of a hotspot, the propagation of a fracture from the Atlas Mountains and mantle 


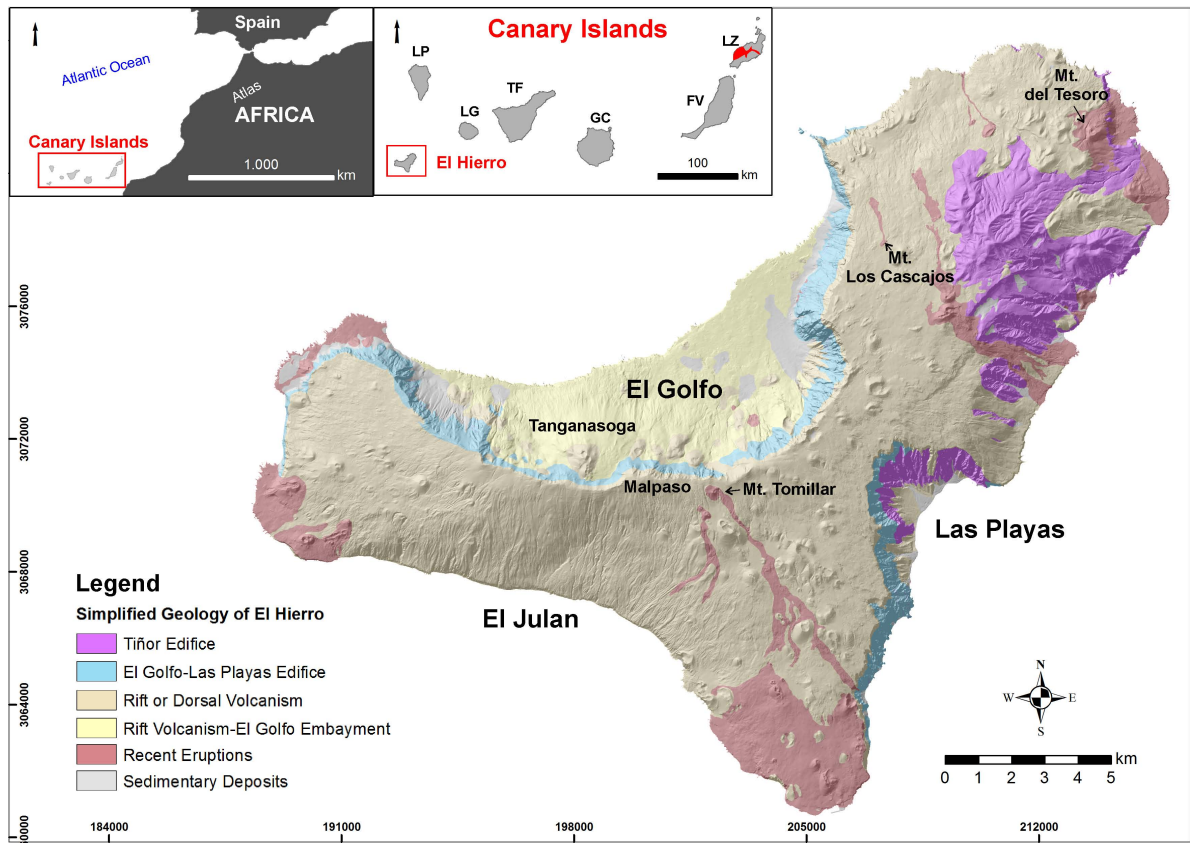

Figure 1. Geological map of El Hierro Island. At the left top part of the figure, location of the Canary Islands is presented where LZ represents Lanzarote; FV represents Fuerteventura; GC represents Gran Canaria; TF represents Tenerife; LG represents La Gomera; LP represents La Palma; EH represents El Hierro. Timanfaya eruption in Lanzarote has been coloured in red.

decompression melting associated with uplift of tectonic blocks - have been mooted to explain the origin of the $\mathrm{Ca}$ nary Islands (Le-Pichon and Fox, 1971; Anguita and Hernán, 1975; Schmincke, 1982; Araña and Ortiz, 1991; Hoernle and Schmincke, 1993; Hoernle et al., 1995; Carracedo et al., 1998; Anguita and Hernán, 2000).

Although all of the islands (except La Gomera) have been witness to Holocene volcanic activity, volcanism has historically been restricted to La Palma, Lanzarote, El Hierro and Tenerife (Fig. 1, inset). In all cases, historical eruptive activity has produced mafic eruptions ranging in intensity from Hawaiian to violent Strombolian (Valentine and Gregg, 2008 and references therein) and have given rise to lavas and scoria cones. Typically, the islands' historical eruptions have occurred in active rift zones along eruptive fissures and have occasionally generated alignments of cones. Other than the case of the Timanfaya eruption in 1730 in Lanzarote (Fig. 1, inset), which lasted for 6 years, the duration of eruptions has ranged from a few weeks to a few months. The total volume of erupted magma ranges from 0.01 to $>1.5 \mathrm{~km}^{3}$ (DRE, dense rock equivalent), the upper extreme occurring in the case of the Timanfaya eruption. In all cases the resulting volcanic cones were constructed during single eruptive episodes (i.e. they should be referred to as monogenetic) that usually involved several distinctive phases with no significant temporal separations between them. Monogenetic volcanic fields consist of individual, commonly mafic volcanoes, built in single, relatively short-lived eruptions. These volcanoes usually take the form of scoria cones, tuff rings, maars or tuff cones; scoria cones are the most common landform and show a great diversity in size, morphology and eruptive products (Valentine and Gregg, 2008; Kereszturi and Németh, 2012). Individual volcanic edifices are characteristically small in volume, typically $<0.1 \mathrm{~km}^{3}$ of DRE, but the eruption can be complex with many different phases and styles of activity (Németh, 2010). Situated in the southwestern corner of the archipelago, El Hierro is the youngest of the Canary Islands; its oldest subaerial rocks have been dated at $1.12 \mathrm{Ma}$ (Guillou et al., 1996). It rises from a depth of $4000 \mathrm{~m}$ to around $1500 \mathrm{~m}$ a.s.l. and has an estimated total edifice volume of about $5500 \mathrm{~km}^{3}$ (Schminke and Sumita, 2010). It corresponds to a shield structure formed by different volcanic edifices and includes three rift zones on which recent volcanism has been concentrated (Guillou et al., 1996; Carracedo et al., 2001) (Fig. 1). Other relevant morphological features include the collapse scars of El Golfo, Las Playas and El Julan (Fig. 1). The emergent parts of these rifts are characterised by steep narrow ridges, corresponding to aligned dyke complexes with clusters of cinder cones. Pre-historical eruptions have been recognised on all three rifts on El Hierro (Guillou et al., 1996; Carracedo et al., 2001).

Recent subaerial volcanism on El Hierro is monogenetic and is mostly characterised by the eruption of mafic magmas as well as the intrusion of subvolcanic bodies ranging in composition from picrobasalts to basanites (Pellicer, 1977; Stroncik et al., 2009), which have generally erupted along the rift zones. Some felsic dykes and lava flows associated with the older parts of the island have also been reported (Guillou 
et al., 1996; Carracedo et al., 2001) but are volumetrically subordinate to the mafic material. In addition, an explosive felsic eruption has been documented in association with the final episodes of the construction of the edifice of El GolfoLas Playas (later than $158 \mathrm{ka}$ ), before it was destroyed by a massive landslide (Pedrazzi et al., 2014). Mafic eruptions typically occur from fissures, and produce proximal fallout, ballistic ejecta and lava flows. PDC deposits have also been reported in cases in which eruptions are related to hydromagmatic episodes (Balcells and Gómez, 1997; Pedrazzi et al., 2014).

The erupted volume of magma in eruptions on El Hierro typically ranges from less than 0.0001 to $0.1 \mathrm{~km}^{3}$ (DRE), values that are of the same order as most of the other historical eruptions on the Canaries (Sobradelo et al., 2011). One of the most important eruptive episodes in the last few thousand years on El Hierro was the Tanganasoga eruption (Fig. 1), which occurred inside the depression of El Golfo along a N-S-oriented fissure, at most $20 \mathrm{ka}$ (Carracedo et al., 2001). Several cones and emission centres formed, giving rise to one of the largest volcanic edifices on the island via the accumulation of ankaramitic lavas and pyroclastic deposits (Carracedo et al., 2001) (Fig. 1). In addition to the subaerial volcanism, bathymetric studies (Gee et al., 2001) have revealed that a significant number of well-preserved volcanic cones exist on the submarine flanks of the island, in particular on the continuation of the southern rift, which suggests that significant submarine volcanic activity has also occurred recently. As a confirmation of this observation, a submarine eruption occurred from 10 October 2011 to the end of February 2012 on the southern rift zone, $2 \mathrm{~km}$ off the coast of $\mathrm{El}$ Hierro (Martí et al., 2013).

\section{Methods}

The spatial probabilities of hosting new vents were estimated using the study by Becerril et al. (2013) of volcanic susceptibility on El Hierro, which takes into account most of the structural data (vents, eruptive fissures, dykes and faults) available from the island. The temporal part of the longterm volcanic hazard assessment was carried out with the Bayesian-event tree-based software HASSET (Sobradelo et al., 2014a) using geochronological data for El Hierro and historical data from the whole archipelago. Hazard scenarios of lava flows, fallout and PDCs were obtained with the VORIS tool (Felpeto et al., 2007) since they are the most likely volcanic scenarios on the island. The data collection required for each hazard assessment was divided into three parts (spatial, temporal, and scenarios), according to the use made of each data set.

\section{How: characterisation of the eruptions}

The characterisation of past volcanic eruptions - typically based on the determination of eruptive parameters derived from the study of erupted products found in the geological records - is crucial for understanding past eruptive behaviour and for forecasting future volcanic activity.

Recent volcanic activity on El Hierro is largely characterised by monogenetic mafic volcanism and the building of more than 220 cones, most of which are scoria cones that correspond to the most recent eruptive cycle (rift volcanism).

Hawaiian and Strombolian activity are the most common eruptive styles observed on the island (Becerril, 2009), which have formed extensive lava flow fields, spatter and cinder cones made of scoria agglutinates and well-bedded lapilli scoria and ash, respectively. Violent Strombolian activity - refereeing to explosive activity that produces sustained eruption columns up to $\sim 10 \mathrm{~km}$ high (without reaching the tropopause) and with the dominant clast sizes being ash to lapilli (Valentine, 1998; Arrighi et al., 2001; Valentine and Gregg, 2008) - has been also recognised through the presence of several distal ash deposits on the geological record of the island. Phreatomagmatic episodes generating rhythmic laminated sequences of coarse juvenile ash and lapillirich beds with accidental lithic fragments also occurred at the interior of the island but in less frequency than those mentioned above. In addition, some hydromagmatic eruptions occurred along the coast, producing tuff ring deposits on the western part of the island (Becerril, 2009). Eruptions related to felsic magmas and producing either trachytic lava flows (Guillou et al., 1996) or trachytic pyroclastic deposits (Pellicer, 1977; Balcells and Gómez, 1997) have also been described. In this sense, it is remarkable that the occurrence of a base-surge-type explosive eruption that generated dilute pyroclastic surge deposits covering an area of more than $15 \mathrm{~km}^{2}$ around the Malpaso area (Fig. 1) (Pedrazzi et al., 2014).

We also took into account the final constructive cycle (158 ka-present) of the island to characterise of the size of the eruptions. The volume of the cones was calculated using ARCGIS 10.0 (ESRI $^{\circledR}$ ) through the analysis of a digital elevation model (DEM), subtracting the current DEM topography to the restored paleo-topography. The volume of lava flows and distal pyroclastic deposits was calculated taking into account their areal extent and thickness variations. This provided a first-order estimate of the erupted volume, despite the lack of a precise paleo-topography. In terms of the total volume of erupted material, the largest eruptions that occurred during the final growing cycle on El Hierro correspond to volumes of the order of 0.15$0.042 \mathrm{~km}^{3}$ (Tanganasoga, Mt. del Tesoro, the latter was calculated by Rodríguez-González et al., 2012). A minimum value is for Mt. Los Cascajos, with just $0.0016 \mathrm{~km}^{3}$. The volcanic explosivity index (VEI) (Newhall and Self, 1982) and dense rock equivalent (DRE) derived from the volumetric 
data of the eruptions were also calculated. Most of VEI values are in the range of $0-2$, whilst the erupted volume of magma (using mean magma density of $2.8 \mathrm{~g} \mathrm{~cm}^{-3}$, an average rock density of $2.44 \mathrm{~g} \mathrm{~cm}^{-3}$ obtained from laboratory analysis of El Hierro samples, and applying the equation: DRE $\left(\mathrm{km}^{3}\right)=$ volume of volcanic deposit $\left(\mathrm{km}^{3}\right) \times$ density of volcanic deposit $\left(\mathrm{kg} \mathrm{m}^{-3}\right)$ /magma density $\left(\mathrm{kg} \mathrm{m}^{-3}\right)$ ) for most of the recent eruptions on El Hierro lies within the range of $0.0001-0.1 \mathrm{~km}^{3}$ (DRE). The DRE calculation was based on the volume of exposed materials (lavas and pyroclastic deposits) so our total volumes are minimum estimates, but similar to those assigned to other monogenetic fields, which normally have volumes between 0.0001 and a few cubic kilometres for individual eruptions (e.g. Kereszturi et al., 2013). For example, the erupted volume of magma on the Canary Islands typically ranges from 0.001 to $0.2 \mathrm{~km}^{3}$ (DRE) (Sobradelo et al., 2011). In the Garrotxa volcanic field (Spain) the total volume of extruded magma in each eruption ranges from 0.01 to $0.2 \mathrm{~km}^{3}$ (DRE) (Bolós et al., 2014). The volumes of basaltic eruptions on Terceira (Açores, Portugal) range in size from $0.1 \mathrm{~km}^{3}$ to less than $0.001 \mathrm{~km}^{3}$ (DRE) (Self, 1976). In the case of Auckland (New Zealand), monogenetic field volumes are in the range of 0.00007 to $0.698 \mathrm{~km}^{3}$ (Kereszturi et al., 2013).

By comparing pre- and post-eruption high-resolution bathymetries, the total bulk volume erupted during the submarine eruption of 2011-2013 was estimated at $0.33 \mathrm{~km}^{3}$ (Rivera et al., 2013).

Most of the lava flows on El Hierro that were emplaced from cones located on and off the rift zones reached the sea. Therefore, it was not possible to measure precisely the maximum lengths of past lava flows. Nevertheless, the Mt. del Tomillar (Fig. 1) lava flow, which did not reach the sea, has a total length of $8 \mathrm{~km}$. However, for further simulations (Sect. 6.1) we considered this value as a minimum length for the lava flows and used $15 \mathrm{~km}$ as a more reliable length. The mean thickness of lava flows was obtained from the average value $(3 \mathrm{~m})$ of individual flows measured in the field.

\section{Where: spatial analysis}

An essential step in obtaining a volcanic hazard map is to determine the most likely areas to host new eruption vents, a task based on the drawing of susceptibility maps based on geological, structural and geophysical data (Martí and Felpeto, 2010). Structural elements such as vents, eruptive fissures, dykes and faults are used to pinpoint areas where next eruptions may most likely occur. A volcanic susceptibility map shows the spatial distribution of vent opening for future eruption and represents the basis for further temporal and spatial probability analysis and the definition of eruptive scenarios. We used the susceptibility map developed by Becerril et al. (2013) following the methodology employed by Cappello et al. (2012) (Fig. 2). This map is based on the

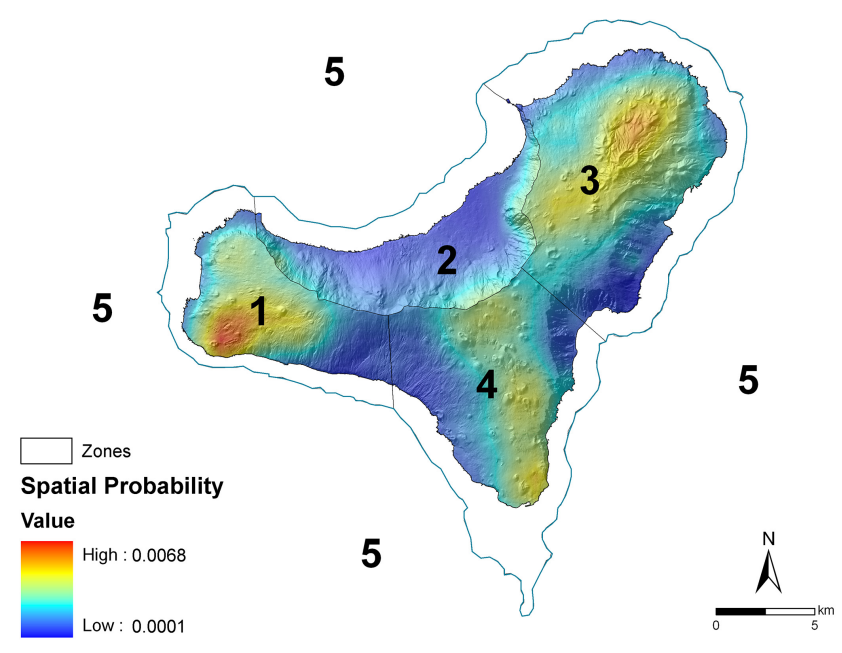

Figure 2. Onshore spatial probability distribution of future volcanic eruptions map of El Hierro Island, showing the divisions of the sectors. Modified from Becerril et al. (2013).

five data sets representing the volcano-structural elements on El Hierro: (1) subaerial vents and eruptive fissures pertaining to the island's rift volcanism, which include sub-recent and recent eruptions; (2) submarine vents and eruptive fissures inferred from bathymetric data; (3) eruptive fissures and emission centres identified on the Tiñor and El Golfo-Las Playas edifices; (4) presence of dykes; (5) and presence of faults.

To carry out this spatial assessment, we subdivided the spatial probability map into 5 sectors (Fig. 2) based on susceptibility values, topographic constraints and expected hazards. First, we differentiated the subaerial and the submarine area, taking into account differences in the expected hazards. After that, the emergent part of the island was subdivided according to areas with different structural controls (different strike of the volcano-structures as dykes and fissures), different topographical constrains (zones 1, 3 and 4 represent rift areas, while zone 2 is an embayment), and different susceptibility values according to the map developed by Becerril et al. (2013). This map enables us to select the areas with the greatest likelihood of hosting future scenarios.

\section{When: temporal analysis}

Temporal analyses were performed using HASSET (Sobradelo et al., 2014a) a Bayesian event tree structure with eight nodes representing different steps to evaluate the temporal probability and evolving from a more general node of unrest to the more specific node of the extent of the hazard (Sobradelo and Martí, 2010).

We based the study of temporal probability on the catalogue of eruptions documented in Table 1. In all, 25 eruptions are documented from the last $158 \mathrm{ka}$, data confirmed by the relative stratigraphy established during our field work. Six of 
Table 1. The principal characteristics of the eruptions identified during the last constructive episode of El Hierro. The eruptions included in this table are those for which geochronological data exist and that are consistent with the field-relative stratigraphy established in this study. In addition to the geochronological data and the corresponding references, the rest of the information included in the table corresponds to information related to the first nodes in the HASSET (Sobradelo et al., 2014a) event tree used in this study. See text for more details.

\begin{tabular}{|c|c|c|c|c|c|c|c|c|}
\hline ID & Unrest & Origin & Outcome & Location & Composition & Hazard & Extent & Reference \\
\hline 1 & 2011 & magmatic & $\begin{array}{l}\text { magmatic } \\
\text { eruption }\end{array}$ & 5 & Mafic & lava flow & medium & $\begin{array}{l}\text { Martí et al. } \\
\text { (2013) }\end{array}$ \\
\hline 2 & 1793 & seismic & no eruption & $?$ & & & & $\begin{array}{l}\text { Hernández } \\
\text { Pacheco (1982) }\end{array}$ \\
\hline 3 & $2500 \pm 70(\mathrm{BP})$ & magmatic & $\begin{array}{l}\text { magmatic } \\
\text { eruption }\end{array}$ & $3 a$ & Mafic & $\begin{array}{l}\text { ballistic }+ \\
\text { lava flow }\end{array}$ & medium & $\begin{array}{l}\text { Carracedo et } \\
\text { al. }(2001)\end{array}$ \\
\hline 4 & 4230 (BP) & magmatic & $\begin{array}{l}\text { magmatic } \\
\text { eruption }\end{array}$ & $3 a$ & Mafic & $\begin{array}{l}\text { ballistic }+ \\
\text { lava flow }\end{array}$ & short & $\begin{array}{l}\text { Fúster et al. } \\
\text { (1993) }\end{array}$ \\
\hline 5 & $8000 \pm 2000(\mathrm{BP})$ & magmatic & $\begin{array}{l}\text { magmatic } \\
\text { eruption }\end{array}$ & $1 \mathrm{a}$ & Mafic & $\begin{array}{l}\text { ballistic }+ \\
\text { lava flow }\end{array}$ & short & $\begin{array}{l}\text { Pérez Torrado } \\
\text { et al. (2011) }\end{array}$ \\
\hline 6 & 9000 (BP) & magmatic & $\begin{array}{l}\text { magmatic } \\
\text { eruption }\end{array}$ & $3 a$ & Mafic & $\begin{array}{l}\text { ballistic }+ \\
\text { lava flow }\end{array}$ & medium & $\begin{array}{l}\text { Rodríguez-González } \\
\text { et al. (2012) }\end{array}$ \\
\hline 7 & $12000 \pm 7000(\mathrm{BP})$ & magmatic & $\begin{array}{l}\text { magmatic } \\
\text { eruption }\end{array}$ & $2 \mathrm{a}$ & Mafic & lava flow & short & $\begin{array}{l}\text { Guillou et al. } \\
\text { (1996) }\end{array}$ \\
\hline 8 & $15000 \pm 3000(\mathrm{BP})$ & magmatic & $\begin{array}{l}\text { magmatic } \\
\text { eruption }\end{array}$ & $2 \mathrm{a}$ & Mafic & lava flow & short & $\begin{array}{l}\text { Guillou et al. } \\
\text { (1996) }\end{array}$ \\
\hline 9 & $15000 \pm 2000(\mathrm{BP})$ & magmatic & $\begin{array}{l}\text { magmatic } \\
\text { eruption }\end{array}$ & $4 \mathrm{~b}$ & Mafic & lava flow & short & $\begin{array}{l}\text { Carracedo et } \\
\text { al. (2001) }\end{array}$ \\
\hline 10 & $21000 \pm 3000(\mathrm{BP})$ & magmatic & $\begin{array}{l}\text { magmatic } \\
\text { eruption }\end{array}$ & $2 \mathrm{a}$ & Mafic & lava flow & short & $\begin{array}{l}\text { Guillou et al. } \\
\text { (1996) }\end{array}$ \\
\hline 11 & $31000 \pm 2000(\mathrm{BP})$ & magmatic & $\begin{array}{l}\text { magmatic } \\
\text { eruption }\end{array}$ & $4 b$ & Mafic & lava flow & short & $\begin{array}{l}\text { Carracedo et } \\
\text { al. (2001) }\end{array}$ \\
\hline 12 & $38700 \pm 12600(\mathrm{BP})$ & magmatic & $\begin{array}{l}\text { magmatic } \\
\text { eruption }\end{array}$ & $2 b$ & Mafic & lava flow & short & $\begin{array}{l}\text { Longpré et al. } \\
\text { (2011) }\end{array}$ \\
\hline 13 & $41000 \pm 2000(\mathrm{BP})$ & magmatic & $\begin{array}{l}\text { magmatic } \\
\text { eruption }\end{array}$ & $4 b$ & Mafic & lava flow & short & $\begin{array}{l}\text { Carracedo et } \\
\text { al. (2001) }\end{array}$ \\
\hline 14 & $44000 \pm 3000(\mathrm{BP})$ & magmatic & $\begin{array}{l}\text { magmatic } \\
\text { eruption }\end{array}$ & $4 \mathrm{~b}$ & Mafic & lava flow & short & $\begin{array}{l}\text { Guillou et al. } \\
\text { (1996) }\end{array}$ \\
\hline 15 & $76000 \pm 6000(\mathrm{BP})$ & magmatic & $\begin{array}{l}\text { magmatic } \\
\text { eruption }\end{array}$ & $3 b$ & Mafic & lava flow & short & $\begin{array}{l}\text { Guillou et al. } \\
\text { (1996) }\end{array}$ \\
\hline 16 & $80000 \pm 40000(\mathrm{BP})$ & magmatic & $\begin{array}{l}\text { magmatic } \\
\text { eruption }\end{array}$ & $3 a$ & Felsic & lava flow & $\begin{array}{l}\text { medium- } \\
\text { large }\end{array}$ & $\begin{array}{l}\text { Fúster et al. } \\
\text { (1993) }\end{array}$ \\
\hline 17 & $86600 \pm 8300(\mathrm{BP})$ & magmatic & $\begin{array}{l}\text { magmatic } \\
\text { eruption }\end{array}$ & $1 \mathrm{a}$ & Mafic & lava flow & short & $\begin{array}{l}\text { Longpré et al. } \\
\text { (2011) }\end{array}$ \\
\hline 18 & $94500 \pm 12600$ (BP) & magmatic & $\begin{array}{l}\text { magmatic } \\
\text { eruption }\end{array}$ & $4 a$ & Mafic & lava flow & short & $\begin{array}{l}\text { Longpré et al. } \\
\text { (2011) }\end{array}$ \\
\hline 19 & $115300 \pm 6900(\mathrm{BP})$ & magmatic & $\begin{array}{l}\text { magmatic } \\
\text { eruption }\end{array}$ & $4 a$ & Mafic & lava flow & short & $\begin{array}{l}\text { Longpré et al. } \\
\text { (2011) }\end{array}$ \\
\hline 20 & 126000 & magmatic & $\begin{array}{l}\text { magmatic } \\
\text { eruption }\end{array}$ & 5 & Mafic & lava flow & short & $\begin{array}{l}\text { Klügel et al. } \\
\text { (2011) }\end{array}$ \\
\hline 21 & $133000 \pm 200$ & magmatic & $\begin{array}{l}\text { magmatic } \\
\text { eruption }\end{array}$ & 5 & Felsic & lava flow & short & $\begin{array}{l}\text { Van der } \\
\text { Bogard (2013) }\end{array}$ \\
\hline 22 & $134000(\mathrm{BP})$ & magmatic & $\begin{array}{l}\text { magmatic } \\
\text { eruption }\end{array}$ & $3 \mathrm{a}$ & Mafic & lava flow & short & $\begin{array}{l}\text { Széréméta et } \\
\text { al. (1999) }\end{array}$ \\
\hline 23 & $142000 \pm 2000(\mathrm{BP})$ & magmatic & $\begin{array}{l}\text { magmatic } \\
\text { eruption }\end{array}$ & 5 & Felsic & lava flow & short & $\begin{array}{l}\text { Van der Bogard } \\
\text { (2013) }\end{array}$ \\
\hline 24 & $145000 \pm 4000(\mathrm{BP})$ & magmatic & $\begin{array}{l}\text { magmatic } \\
\text { eruption }\end{array}$ & $3 b$ & Mafic & lava flow & short & $\begin{array}{l}\text { Guillou et al. } \\
\text { (1996) }\end{array}$ \\
\hline 25 & $158000 \pm 4000(\mathrm{BP})$ & magmatic & $\begin{array}{l}\text { magmatic } \\
\text { eruption }\end{array}$ & $3 a$ & Mafic & lava flow & short & $\begin{array}{l}\text { Guillou et al. } \\
\text { (1996) }\end{array}$ \\
\hline
\end{tabular}


these eruptions took place during the previous 11700 years (Holocene), but only 2 unrest episodes have been documented in the last 600 years (historical period). The information from these eruptions was used to characterise the past eruptive activity on El Hierro and to estimate some of the input parameters required for our hazard assessment.

However, due to the scarcity of dated eruptions and to the certainty that not all the eruptions that occurred in this period have been identified and/or dated, we also used in our temporal analysis as data for the last 600 years (15th century to 2013) the historical data set for the whole of the Canary Islands (see Sobradelo et al., 2011). Therefore, using HASSET we were able to estimate the probability that a volcanic episode will occur in the forecasting time interval (the next 20 years). Given that the data set time window is 600 years, we thus obtained 30 time intervals of data for the study period. Here we restrict our data set to the historical period, which includes the recent submarine eruption (2011) and the seismic unrest of 1793 . The remaining 23 eruptions in this catalogue - referred to as pre-historical - will be used to assign prior weights to nodes 2 to 8 .

\section{Input data for HASSET}

\subsection{Node 1: unrest}

This node estimates the temporal probability of a reawakening of the system in the next time window by examining the number of past, non-overlapping, equal-length time windows that encompass an episode of unrest. Implicitly, this node estimates the recurrence time with a Bayesian approach that does not use the time series. It did not take into account the repose period between eruptions or the possible non-stationary nature of the data. However, Sobradelo et al. (2011) used extreme value theory to study the historical recurrence of monogenetic volcanism on the Canary Islands since the first written records appeared at the beginning of the 15 th century. By modelling the inter-period times with a nonhomogeneous generalised Pareto-Poisson distribution, this study estimated as of 2010 that the probability of an eruption of a magnitude $>2$ anywhere on the Canary Islands in the next 20 years was $0.97 \pm 0.00024$.

In order to compute the probability of having (at least) an unrest episode in the next 20 years, we need two pieces of information: (1) our starting beliefs or weights for each possibility (yes, no) and (2) the number of past events during the period of study. As per the number of past events, it shows that in the last 600 years (historical period), there have been two episodes of unrest identified at El Hierro (a seismic unrest and the latest magmatic unrest in 2011 which resulted in eruption). As per the starting weights for each option, if we did not have any information at all we would start with the state of total ignorance or total epistemic uncertainty, and give 50/50 chance to each option. However, this is not the case, as in the study of the volcanic recurrence for the Canary Islands as of 2010 (based on volcanic records from the islands of Tenerife, La Palma and Lanzarote) (Sobradelo et al., 2011), there is an estimated $97 \%$ probability of at least one eruption in the next 20 years, anywhere on the Canary Islands (including El Hierro). Therefore, rather than starting with a $50 / 50$ chance, this study allowed us to assign our a priori beliefs for the "unrest" node in the island of El Hierro (yes = 97, no $=3$ ), and then we used the 2 historical episodes of unrest documented in El Hierro to update those initial beliefs.

The reason why we used the 2 historical events in the catalogue of El Hierro, and not the remaining 23 pre-historical events, was to avoid misleading results in the probability of unrest. If we had used the entire catalogue we would have said to the model that there was on average 1 eruption every 7900 years $(158000 / 20)$, which is not realistic, as the catalogue is incomplete. For that reason we updated our prior beliefs with the historical part of the catalogue that we were most confident with. Given our confidence in these results, we were able to assign an epistemic uncertainty of 50 to our data weights, which means that new evidence regarding intervals with non-eruptive behaviour will not significantly modify our prior assumptions. As shown by the posterior probabilities in column 6 of Table 2, despite 28 intervals out of 30 (600 years/20 estimated time intervals) with no unrest, the posterior probability of unrest in the next 20 years is still significantly large.

\subsection{Node 2: origin}

We considered four types of unrest that could occur on El Hierro: magmatic, geothermal, seismic and others. In spite of the predominant magmatic and seismic behaviour in past activity, we cannot exclude either geothermal activity or false unrest. In fact, hydromagmatic deposits exist in the interior of the island that were most probably associated with the presence of shallow aquifers. Some of these deposits also contain hydrothermally altered lithic clasts, which also suggest the existence of localised hydrothermal systems. Thus, it was impossible to rule out the possibility of geothermal unrest. False unrest can occur when non-volcanic signals are recorded together with volcanic signals. For example, changes in the gravity field, ground deformation or even seismicity unrelated to any volcanic activity could be associated with variations in the recharge and/or extraction of meteoric water into/from aquifers in El Hierro. Even so, we still believe that in monogenetic volcanism magmatic changes are the main source of unrest and so we gave the greatest weight to magmatic unrest (0.96) and split the rest evenly among the other options. The prior weights were assigned on the basis of a priori beliefs and so we allocated a value of 10 to the epistemic uncertainty since we still expect the majority of unrest to be of magmatic origin. However, it is still important to give more weight to new evidence. 
Table 2. Input data for HASSET (columns 1 to 5) and output probability vectors and standard deviations (columns 6 and 7). Prior weights and data weights are estimated using pre-historical data, a priori beliefs and published studies on global volcanic unrest during the last century. Past data are based on the eruptions recorded in the last 600 years, considered as the historical period for the Canary Islands.

\begin{tabular}{llclccc}
\hline $\begin{array}{l}\text { Node } \\
\text { name }\end{array}$ & Event & $\begin{array}{c}\text { Past } \\
\text { data }\end{array}$ & $\begin{array}{l}\text { Prior } \\
\text { weight }\end{array}$ & $\begin{array}{c}\text { Data } \\
\text { weight }\end{array}$ & $\begin{array}{c}\text { Probability } \\
\text { estimate }\end{array}$ & $\begin{array}{c}\text { Standard } \\
\text { deviation }\end{array}$ \\
\hline Unrest & Yes & 2 & 0.97 & 50 & 0.64 & 0.07 \\
Unrest & No & 28 & 0.03 & 50 & 0.36 & 0.07 \\
Origin & Magmatic & 1 & 0.94 & 10 & 0.88 & 0.09 \\
Origin & Geothermal & 0 & 0.02 & 10 & 0.02 & 0.03 \\
Origin & Seismic & 1 & 0.02 & 10 & 0.08 & 0.07 \\
Origin & Other & 0 & 0.02 & 10 & 0.02 & 0.03 \\
Outcome & Magmatic eruption & 1 & 0.64 & 10 & 0.62 & 0.13 \\
Outcome & Sector failure & 0 & 0.12 & 10 & 0.10 & 0.08 \\
Outcome & Phreatic explosion & 0 & 0.12 & 10 & 0.10 & 0.08 \\
Outcome & No eruption & 1 & 0.12 & 10 & 0.17 & 0.10 \\
Location & Zone 1 & 1 & 0.16 & 50 & 0.17 & 0.05 \\
Location & Zone 2 & 0 & 0.07 & 50 & 0.07 & 0.03 \\
Location & Zone 3 & 0 & 0.29 & 50 & 0.28 & 0.06 \\
Location & Zone 4 & 0 & 0.16 & 50 & 0.15 & 0.05 \\
Location & Zone 5 & 1 & 0.32 & 50 & 0.33 & 0.06 \\
Composition & Mafic & 1 & 0.87 & 10 & 0.88 & 0.09 \\
Composition & Felsic & 0 & 0.13 & 10 & 0.12 & 0.09 \\
Size & VEI 1- & 0 & 0.31 & 1 & 0.25 & 0.19 \\
Size & VEI 2 & 1 & 0.62 & 1 & 0.70 & 0.21 \\
Size & VEI 3+ & 0 & 0.07 & 1 & 0.06 & 0.10 \\
Size & n.a. & 0 & 0 & 0 & 0.00 & 0.00 \\
Hazard & Ballistic & 1 & 0.12 & 10 & 0.15 & 0.09 \\
Hazard & Fallout & 1 & 0.05 & 10 & 0.09 & 0.07 \\
Hazard & PDC & 0 & 0.03 & 10 & 0.03 & 0.04 \\
Hazard & Lava flow & 1 & 0.8 & 10 & 0.73 & 0.11 \\
Hazard & Lahars & 0 & 0 & 0 & 0.00 & 0.00 \\
Hazard & Debris avalanche & 0 & 0 & 0 & 0.00 & 0.00 \\
Hazard & Other & 0 & 0 & 0 & 0.00 & 0.00 \\
Extent & Short & 0 & 0.87 & 10 & 0.80 & 0.11 \\
Extent & Medium & 1 & 0.09 & 10 & 0.16 & 0.10 \\
Extent & Large & 0 & 0.04 & 10 & 0.04 & 0.05 \\
\hline & & & & & & \\
\hline
\end{tabular}

\subsection{Node 3: outcome}

A study of global volcanic unrest in the 21 st century (Phillipson et al., 2013) shows that $64 \%$ of unrest episodes lead to eruptions. On the other hand, in light of previous studies on El Hierro (Carracedo et al., 2001; Pedrazzi et al., 2014), we were unable to rule out the possibility that, aside from a magmatic eruption, a sector failure or a phreatic explosion might also follow on from an episode of unrest.

Therefore, we assigned a weight of 0.64 to the magmatic eruption and split the remaining 0.36 evenly between the alternative nodes. As these weights were assigned based on general studies and a priori beliefs that did not necessarily include data from El Hierro, we gave a value of 10 to the epistemic uncertainty. As with the previous node, we did not give a total epistemic uncertainty, as we still believe that the largest weight should be for the magmatic eruption branch; however, we still want new evidence to be able to contribute significantly to updating our prior weights. The two data points in our historical catalogue already include an episode of unrest that did not evolve into an eruption and so we should expect the prior weight of 0.12 assigned to the "No eruption" node to be substantially increased after the new evidence is entered in the model and the posterior probabilities are computed (Table 2, column 6).

\subsection{Node 4: location}

We divided the island into 5 zones and 11 subzones to be able to perform a volcanic hazard assessment of El Hierro based on the past geological information described above (Fig. 3). These five main zones were established according to the structural (susceptibility) and topographic characteristics of the island, whilst the subdivisions were made by taking into account the potential occurrence of hydrovolcanic episodes. Thus, subzones $1 \mathrm{~b}-4 \mathrm{~b}$ represent areas that 


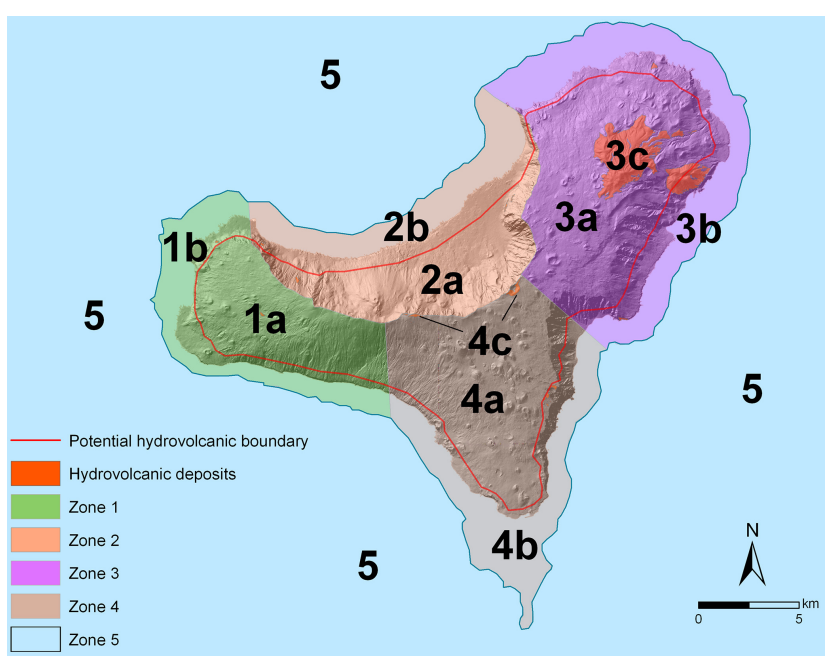

Figure 3. Sectors and subsectors defined on El Hierro. Sectors 1-4 show onshore division while sector 5 represents the offshore area. The division is based on differences in structural patterns, spatial probability of hosting new vents and expected hazards. Subsectors a-c take into account the potential occurrence of hydrovolcanic episodes.

could include the focus of and/or be affected by hydrovolcanic episodes caused by the interaction of seawater with the erupting magma. Given the data, regarding such episodes in the past geological record, we considered that the offshore zone between the bathymetric line of $200 \mathrm{~m}$ and the onshore area near the coast, which already includes several hydrovolcanic edifices, was suitable for the occurrence of such processes (Fig. 3). Moreover, subzones $3 \mathrm{c}$ and $4 \mathrm{c}$ in the interior of the island provide evidence of phreatomagmatic eruptions in the past.

The susceptibility analysis of the island, based on the study by Becerril et al. (2013) (Fig. 2), allowed us to assign the prior weights to each node with a high degree of confidence, as shown in Table 2 . The reliability of the susceptibility map enables us to assign a data weight of 50 (since the prior weights were estimated using past data from El Hierro) accounting for the uncertainties in the data catalogue. For this reason, we felt very confident in the initial distribution of the prior weights and any new evidence is likely to confirm them. Of the two historical events, one was in zone 5 (20112012 eruption). This unrest lasted 4 months before leading to an eruption which was fully monitored by the Instituto Geográfico Nacional (López et al., 2012).The other one refers to the 1793 seismic unrest whose location is uncertain, although historical documents describe it as being in the northwest submarine area, i.e. zone 5 .

\subsection{Node 5: composition}

From the pre-historical set of 23 eruptions shown in Table 1, $87 \%$ correspond to mafic events and $13 \%$ to felsic events.
As we were aware of the incompleteness of the data catalogue, especially in the oldest part, we were not confident if this was indeed the proportion for the composition of prior weights. Some - or many - felsic eruptions may not be documented for example, the Malpaso member, a felsic explosive eruption, has been identified on the upper part of El Golfo-Las Playas volcano (Pedrazzi et al., 2014) but was not included in our catalogue because we lack a precise date. The prior weights are not random, as they are based on welldocumented data. For this reason, we assigned an epistemic uncertainty of 10 to our data weights so that if new evidence arrives, these prior values are still accounted for (but more so if there is new evidence), thereby ensuring that any new data will contribute significantly to updating our prior beliefs.

\subsection{Node 6: size}

The erupted volume of magma on the Canary Islands typically ranges from $0.001-0.2 \mathrm{~km}^{3}$ (DRE) (Sobradelo et al., 2011). Due to a lack of accurate volume data, we assumed that volume values on El Hierro were of the same order as in most of the historical eruptions in the Canaries. The last eruption (2011-2012) was characterised by lava flows of medium extent with VEI 2 and so, by using this information, we were able to assign the weights for VEI 1, VEI 2 and VEI 3, as 0.31, 0.62 and 0.07 , respectively.

In the particular case of El Hierro, we observed cases of hydrovolcanic episodes associated with PDC. This would imply VEI sizes that are greater than those on which these prior weights are estimated. Furthermore, the data documented in Sobradelo et al. (2011) is based on Magnitude size, as there was not enough information to estimate the corresponding VEI. For this reason and owing to the lack of magnitude information for the catalogue of eruptions on $\mathrm{El}$ Hierro, we were not confident of the prior weights assigned and so an epistemic uncertainty value of 1 was the most appropriate, and would also ensure that if new evidence arrives for different sectors, it will contribute significantly to updating our prior knowledge. In this way, we gave more weight to the new evidence than to our prior beliefs.

\subsection{Node 7: hazard}

Based on past activity, possible eruption products include ballistic ejecta, fallout, PDCs and lava flows with the prior weights shown in Table 2, computed using the 23 pre-historic eruptions in Table 1 . Most mafic eruptions generated lava flows and proximal fallout. However, a revision of the deposits generated from past volcanic events also reveals that some eruptions located close to the coastline correspond to hydrovolcanic episodes generating PDC deposits. In a similar way, some of the hydrovolcanic deposits found on land near the coast in fact originated from very shallow submarine eruptions. Thus, there is reason to include in subzone $b$ (Fig. 3) both coastal and offshore zones to a maximum depth 
of $200 \mathrm{~m}$, based on the assumption that vents located in these subzones could generate hydrovolcanic phases and produce PDCs.

Of all the possible hazard products, we were confident that ballistic ejecta, fallout, PDCs and lava flows could occur and so we gave zero weight to the remaining options (lahar, debris avalanche and others). However, for the same reasons given for the composition weights (felsic vs. mafic), we assigned a value of 10 to the epistemic uncertainties, as these data weights could change if we had a more complete data catalogue; however, they are still not completely uninformative, as they are based on past records. In this way, we ensure that new evidence will be well accounted for in new updates and that prior weights are not fully dropped when this new evidence arrives.

\subsection{Node 8: extent}

Extent refers to the distance reached by eruption products (lava flows, ballistic ejecta, fallout and PDCs) from eruption points that can be deduced from the geological record. The extent of products from the eruptions documented on El Hierro is comparable to those on the rest of the Canary Islands. We considered small distances for those short lava flows that reach up to $5 \mathrm{~km}$, medium distances $(5-15 \mathrm{~km})$ for PDC deposits, ballistics and lava flows that reach the sea, and large extent mainly for fall out deposits that can expand more than $15 \mathrm{~km}$. As with the previous node, on the basis of data from the oldest eruptions (Table 1), $87 \%$ of extents are small, while $9 \%$ are medium and $4 \%$ large. We assigned a positive weight to a scenario that gives rise to a large extent of products that will account for the potentially more explosive eruptions seen in the geological record that relate to felsic eruptions or even hydromagmatic eruptions. For the same reasons given for the previous node, we assigned an epistemic value of 10 to all branches.

\section{Results}

Columns 6 and 7 in Table 2 show the output from HASSET. Although we started with 28 time windows with no unrest, the posterior probability of unrest in the next 20 years is significantly large $(64 \% ; 36 \%$ for no unrest), due to the high value of the data weight. The same effect occurs with the node location, in which the posterior probabilities remain in the same proportion as the prior weights. The episode of seismic unrest in 1793 has updated our prior beliefs from 2 to $8 \%$, given that we assigned low confidence levels to the initial values. In general, comparing columns 4 and 6 in Table 2, we can see how past data can significantly change the prior probabilities for which we assumed low confidence (10 or less - large epistemic uncertainty), while prior weights assigned with high confidence remain consistent after new evidence is entered in the model.
Looking at the different scenarios (as a combination of the first nodes and branches up to node location) (Table $3 \mathrm{a}$ ), we see that the 5 most likely scenarios are a basaltic eruption with magmatic unrest in zones 5, 3, 1, 4 and 2 (in that order) with probabilities of occurrence over the next 20 years of $0.11 \pm 0.04,0.10 \pm 0.03,0.06 \pm 0.02,0.05 \pm 0.02$ and $0.02 \pm 0.01$, respectively, for any VEI and any type of hazard or extent. However, although some of these estimates have a large standard deviation due to sizeable uncertainties in the input data, they are consistent with observations from the past. Thus, using the information in the data catalogue, we estimated the long-term probability of a basaltic eruption with magmatic unrest in zone 5 (submarine area) occurring in the next 20 years to be $0.11 \pm 0.04$.

If we now look at the most likely scenarios that also include size, hazard and the extent of the eruption, the five next most likely scenarios are basaltic eruptions of VEI 2 with magmatic unrest that generate short lava flows. However, in this case zone 2 is no longer among the 5 most likely scenarios and an eruption in zone 5 with a VEI of 1 or less becomes the fifth most likely to occur in the next 20 years (probability of $0.01 \pm 0.01)$. Once again, the standard deviation for these estimates is large, implying that the variability due to uncertainties in the input data is also large. In this case, we estimated that the most probable scenario $(0.04 \pm 0.02)$ is a submarine (zone 5) mafic magmatic eruption of VEI 2 generating short lava flows.

\section{Eruptive scenarios}

Hazard assessment must be based on the simulation of different volcanic processes across the susceptibility map (e.g. Martí et al., 2012). In order to illustrate potential future eruptions on El Hierro, we simulated scenarios assuming the results obtained with HASSET and considering the most probable hazards (i.e. lava flows, fallout and PDCs) that could occur in the event of such eruptions. We mainly considered eruptions that occur on land or in shallow submarine environments (at a depth of less than $200 \mathrm{~m}$ ) (Fig. 3). We did not consider deeper submarine eruptions even though their socio-economic impact may in fact not be negligible, as seen in the 2011-2012 eruption. However, we assumed that the direct impact of hazards caused by these deeper submarine eruptions on the island was not relevant for the purpose of this study.

For the simulations we used light detection and ranging (LIDAR) technology based on the digital elevation model (DEM) of the island with a cell size of $10 \mathrm{~m}$ generated by the National Geographic Institute (IGN).

\section{Lava flow scenarios}

Bearing in mind the previously obtained susceptibility values (Fig. 2) (Becerril et al., 2013), we simulated lava flow 
Table 3. (a) Most likely scenarios for node location. (b) Most likely scenarios for node extent.

\begin{tabular}{|c|c|c|}
\hline Scenario & $\begin{array}{l}\text { Probability } \\
\text { estimate }\end{array}$ & $\begin{array}{l}\text { Standard } \\
\text { deviation }\end{array}$ \\
\hline \multicolumn{3}{|l|}{ (a) } \\
\hline 1. Yes-magmatic-magmatic eruption-Zone 5 & 0.11 & 0.04 \\
\hline 2. Yes-magmatic-magmatic eruption-Zone 3 & 0.10 & 0.03 \\
\hline 3. Yes-magmatic-magmatic eruption-Zone 1 & 0.06 & 0.02 \\
\hline 4. Yes-magmatic-magmatic eruption-Zone 4 & 0.05 & 0.02 \\
\hline 5. Yes-magmatic-magmatic eruption-Zone 2 & 0.02 & 0.01 \\
\hline \multicolumn{3}{|l|}{ (b) } \\
\hline $\begin{array}{l}\text { 1. Basaltic eruption with magmatic unrest in zone } 5 \text {, } \\
\text { VEI } 2 \text {, that generates lava flows of short extent }\end{array}$ & 0.04 & 0.02 \\
\hline $\begin{array}{l}\text { 2. Basaltic eruption with magmatic unrest in zone } 3 \text {, } \\
\text { VEI } 2 \text {, that generates lava flows of short extent }\end{array}$ & 0.04 & 0.02 \\
\hline $\begin{array}{l}\text { 3. Basaltic eruption with magmatic unrest in zone } 1 \text {, } \\
\text { VEI } 2 \text {, that generates lava flows of short extent }\end{array}$ & 0.02 & 0.01 \\
\hline $\begin{array}{l}\text { 4. Basaltic eruption with magmatic unrest in zone } 4 \text {, } \\
\text { VEI } 2 \text {, that generates lava flows of short extent }\end{array}$ & 0.02 & 0.01 \\
\hline $\begin{array}{l}\text { 5. Basaltic eruption with magmatic unrest in zone } 5 \text {, } \\
V E I \leq 1 \text {, that generates lava flows of short extent }\end{array}$ & 0.01 & 0.01 \\
\hline
\end{tabular}

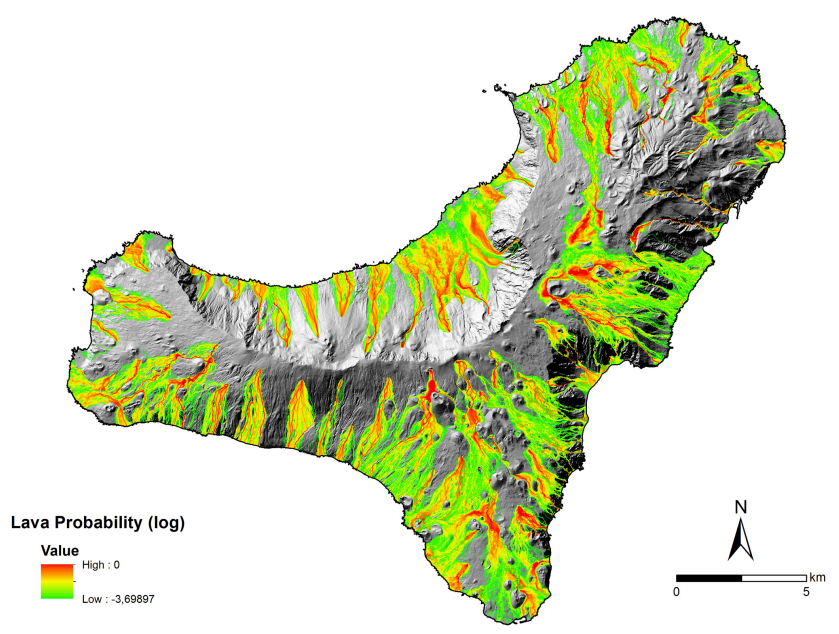

Figure 4. Lava flow scenarios for El Hierro performed with VORIS 2.0.1. Vents from lava flows that have been simulated represent those with the highest spatial probabilities (see susceptibility map in Fig. 2). Red colours are those areas with the highest probability to be invaded by lava flows.

scenarios taking into account only those pixels located on land (lava flows generated in submarine eruptions, even in shallow waters, were assumed not to cause any direct impact on the island). Lava flow simulations based on VORIS 2.0.1 rely on a probabilistic model that assumes that topography is the most important factor in determining the path of a lava flow (Felpeto et al., 2007 and references therein). As explained before, simulations of lava flows were conducted on land and are based on the pixels that lie on the different spatial probability values ranging from 0.00037 to 0.0068 .

In the model, the input parameters for the lava flows were constrained by maximum flow lengths and thicknesses taken from field measurements. Considering that most lava flows in the past reached the sea, we assumed flow lengths of about $15 \mathrm{~km}$. The thickness used as input for the models was $3 \mathrm{~m}$, which was obtained from the average value of individual flows measured in the field. The results provide a map that gives the probability that any particular cell is invaded by a lava flow (Fig. 4).

\section{Scenarios for pyroclastic density currents (PDCs)}

The pyroclastic density currents (PDCs) identified on El Hierro are all associated with hydrovolcanic episodes and mostly relate to mafic vents located in the coastal zone, or episodes occurring at shallow submarine depths that generated deposits that are now exposed along the coast. However, we also considered the possibility that this type of explosive episode could occur on land with more evolved compositions and larger run-out distances, as is the case of the Malpaso member identified in the centre of the island (Pedrazzi et al., 2014). PDCs were simulated with an energy cone model (Sheridan and Malin, 1983) using as input parameters topography, the collapse equivalent height $(H)$ and the collapse equivalent angle $(\theta)$, which is obtained through the 
arctangent of the ratio between $H_{\mathrm{c}}$ and $L$, where $L$ represents the run-out length (Felpeto et al., 2007; Toyos et al., 2007). Run-out distances were considered to be equivalent to the most distal exposure of PDC deposits found on the island, which were calculated to have lengths of 5,1 and $0.5 \mathrm{~km}$. These distances are relative to the most distal deposits of the studied PDCs.

Collapse equivalent heights were chosen in the range of 250-300 $\mathrm{m}$ above the possible vent site in order to constrain the best Hc that matches real deposits. Based on the calibration, a collapse equivalent of 250 and an angle of $11^{\circ}$ were determined for a pyroclastic flow deposit, resembling the known Malpaso member felsic flow deposit. For those vents located in the coastal zone or associated with mafic eruptions, we simulated PDCs with a collapse equivalent of $250 \mathrm{~m}$ and angles in the range of around $4-27^{\circ}$ (low values for base surge explosions and high values for column collapse phases) (Sheridan and Malin, 1983). Although the topography of the area has been modified since the eruption of the Malpaso member, the area and extent of the simulated deposits were still similar to the real PDC deposit. With these constraints, PDC simulations were carried out in the areas with the highest spatial probabilities (Fig. 5a). The areas close to the PDC deposits of El Hierro were also selected to simulate scenarios (Fig. 5b). Figure 5a and b show coverage areas with different Heim coefficients and VEI values.

\section{Fallout}

Fallout from the eruptions on El Hierro was simulated by assuming a violent Strombolian eruption (e.g. Tanganasoga eruption, Fig. 1), characterised by the formation of an eruptive column up to $10 \mathrm{~km}$ high (Arrighi et al., 2001), having significant impacts over distances of several tens of kilometres from the vent (Valentine and Gregg, 2008), which would represent one of the most probable high intensity eruptions that could occur on the island. Nevertheless, we do not rule out the possibility of a subplinian eruption, characterised by columns ranging between 10 and $20 \mathrm{~km}$ altitude, having potential impacts over much larger regions and even globally (Valentine and Gregg, 2008 and references therein) in the event that more felsic magmas are involved in the process. Simulations were conducted using an advection-diffusion model based on the assumption that particle motion is controlled by advection from wind, particle diffusion and their terminal settling velocity (Pfeiffer et al., 2005; Felpeto et al., 2007). All the simulations were conducted with one vent located in the highest spatial probability area and another on the eastern side of the island, the most vulnerable area for a volcanic event and where the main villages, airport and port are situated.

Data inputs of wind profiles were compiled from the University of Wyoming Department of Atmospheric Science sounding database (http://weather.uwyo.edu/upperair/
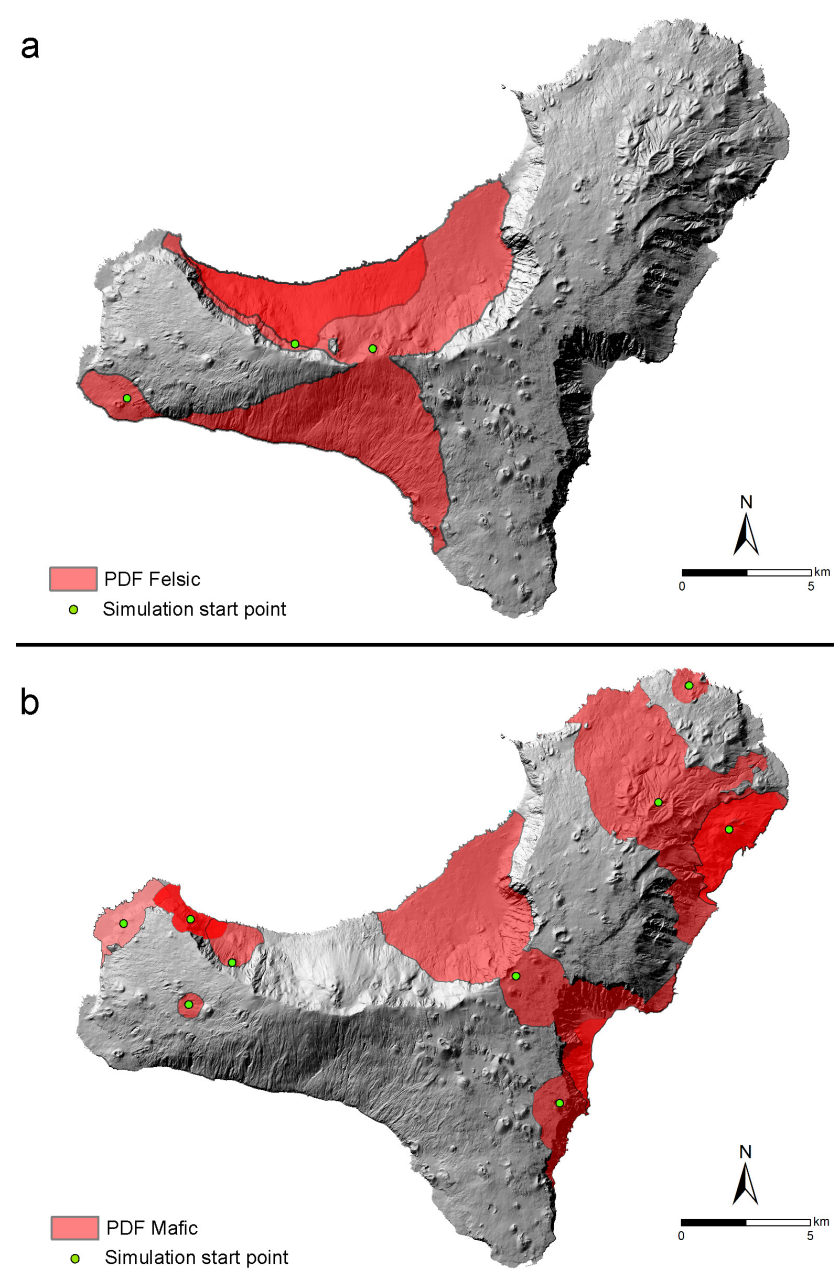

Figure 5. PDC scenarios performed with VORIS 2.0.1. Covered areas with different collapse equivalent heights $\left(H_{\mathrm{c}}\right)$, collapse equivalent angles $(\theta)$ and VEI values (see the text for more detail). (a) VEI 2 corresponding to felsic eruptions; (b) VEI 1 corresponding to mafic eruptions.

sounding.html). We focused the attention of our study on the fallout scenarios for the average wind value of each season during the last decade. Wind direction and intensity were chosen at different vertical heights (500, 1000, 2000, 4000 and $6000 \mathrm{~m}$ ).

Input parameters for the simulation were obtained from fieldwork and bibliographic data. Results are shown in Fig. 6, with particle distribution in a $5 \mathrm{~km}$ high eruptive column related to a violent Strombolian eruption, generating $0.03 \mathrm{~km}^{3}$ of deposits. Particle sizes were considered in a range from -6 to $2 \Phi$, thereby covering the entire range of particle sizes observed in the field. 


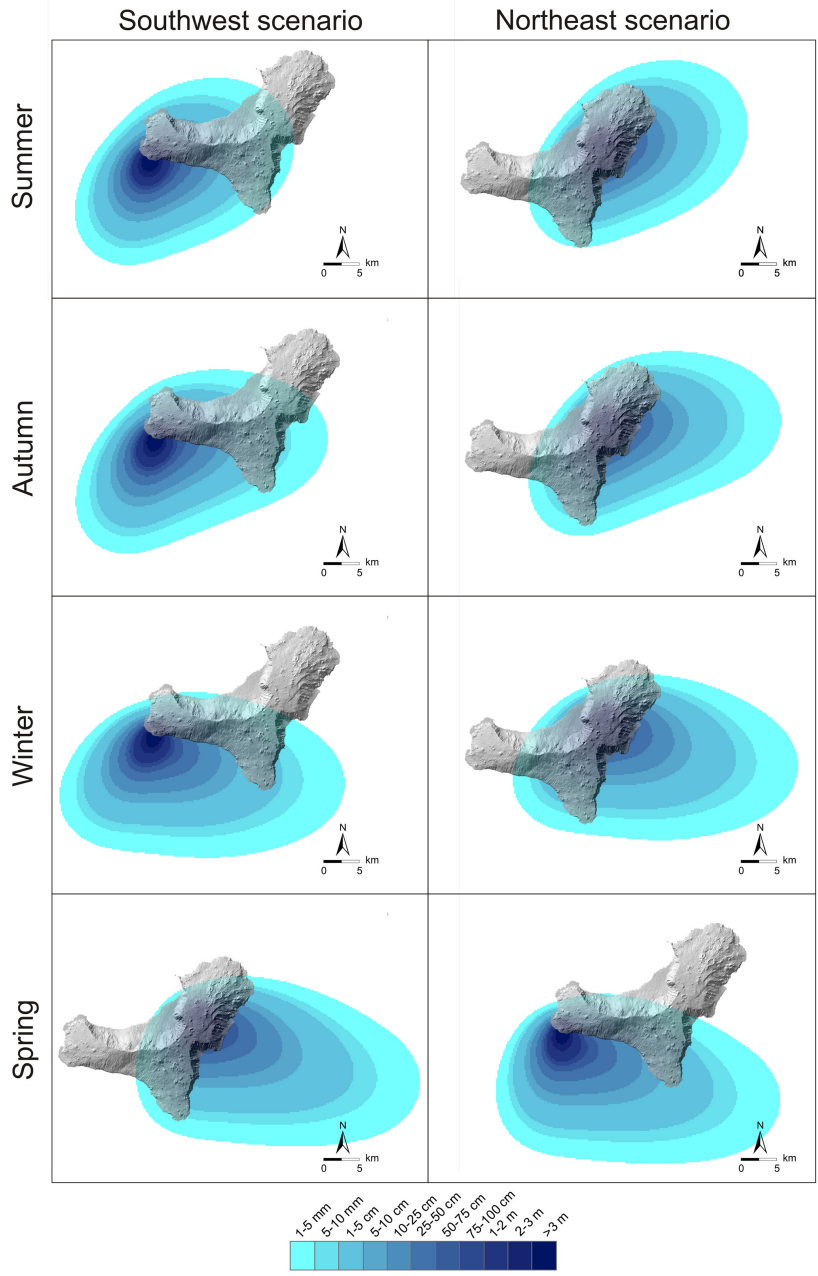

Figure 6. Ashfall scenarios from a violent Strombolian eruption performed with VORIS 2.0.1. (1) Simulation at the highest probability vent; (2) simulation at an area close the main areas of population. Both simulations were performed for summer, autumn, winter and spring.

\section{Total hazard map}

Combination of the most probable scenarios related to basaltic eruptions of VEI 2 that generate lava flows, fallout and PDCs in case of hydrovolcanic events, provided the first total qualitative volcanic hazard map of El Hierro (Fig. 7b). The most probable areas to be affected by the three most likely scenarios were used to define the areas with the greatest and lowest overall volcanic hazard (Fig. 7b). This is an approach similar to that taken by Lindsay et al. (2005) in the Lesser Antilles. We distinguished four levels of hazard depending on the number of individual hazards (Fig. 7a) that overlap on each point (pixel) of the map. The superposition was done taking into account the spatial probability and the extension of each scenario, given more weight to the most probable scenario, i.e. lava flows originating from areas with high spatial vent opening probability. The resulting
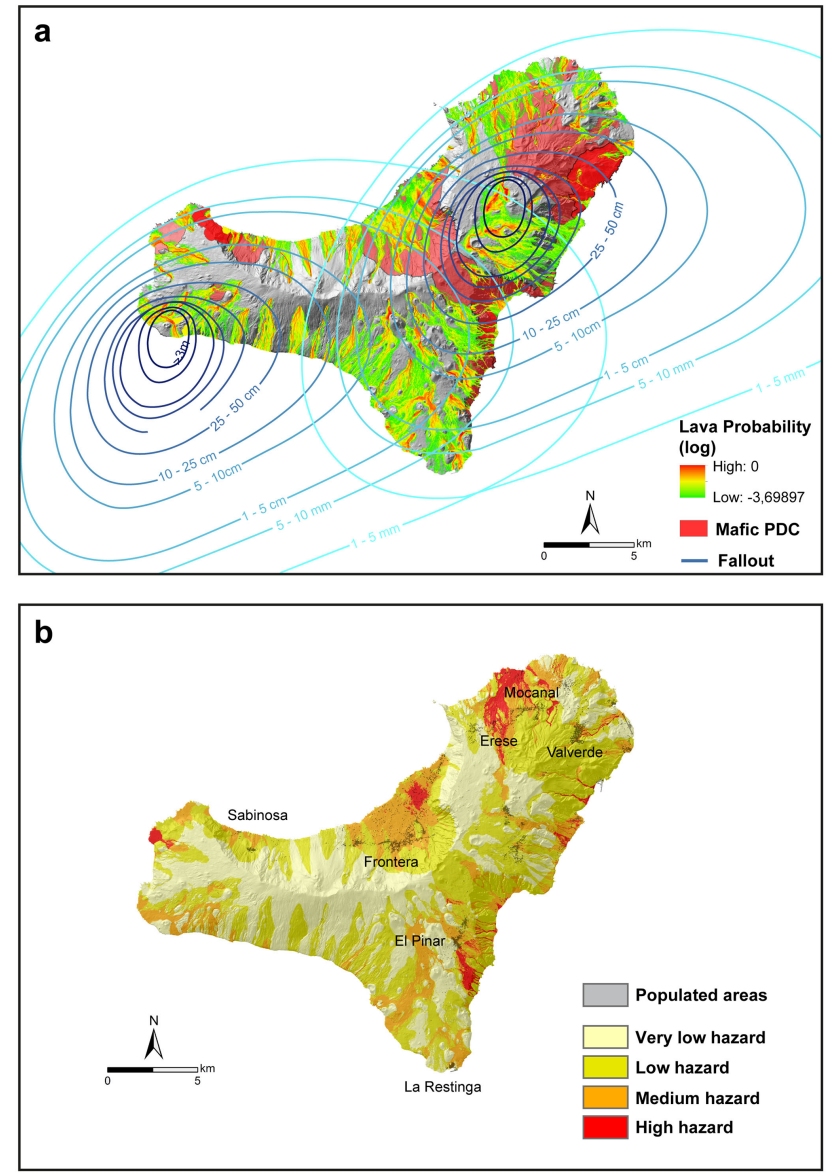

Figure 7. (a) Superposition of the most probable scenarios; (b) qualitative hazard map of El Hierro (zones 1-4) constructed from the combination of the most likely scenarios. This map shows the overall integrated volcanic hazard zones for El Hierro based on lava flows, PDCs and ashfall scenarios. We distinguish four levels of hazard, from very low to high hazard, depending on the number of individual hazards that overlap on each point (pixel) of the map (see text for more explanation).

map shows that, although El Hierro is not a highly populated island, some medium- and high-volcanic-hazard zones coincide with some of the main inhabited areas. However, it must be noted that this hazard level delineation is reliant on the current information, which may be subject to further revision thus implying possible changes in the hazard assessment.

\section{Discussion and conclusions}

Mafic monogenetic eruptions (Table 1) are the most common eruption type to have occurred in El Hierro's recent geological past, especially over the last $158 \mathrm{ka}$ (Pellicer, 1977, 1979). Consequently, we assume that they also represent the most likely eruption types in the near future. These eruptions generated small-size cones, lava flows, proximal scoria, fallout 
and, occasionally, PDCs. The size of most of these eruptions ranged from typical Strombolian to violent Strombolian (some of them associated with hydrovolcanic phases). In Fig. 7a the most likely expected scenarios on the island are represented together. The presence of a relatively recent eruption of phonolitic composition of medium size called Malpaso member and described as a PDC (Pedrazzi et al., 2014) is also remarkable, as it opens up the possibility that eruptions other than monogenetic magmatic and/or hydrovolcanic mafic ones may also occur on El Hierro. Although associated with much greater hazard intensities, this type of eruption has a much lower probability of occurrence.

The catalogue of eruptions that have occurred on El Hierro in the last $158 \mathrm{ka}$ is far from complete. This is evident when trying to establish the relative stratigraphy of volcanic deposits, as there are a large number of units of known origin intercalated between the reported units. Although the establishment of a complete volcano-stratigraphy of El Hierro (and, in particular, of its last constructive episode) is still required, the available number of reported eruptions (for which the corresponding geochronology based on radiometric dating exists) is large enough to provide a preliminary volcanic hazard assessment with a sufficient degree of confidence.

The application of available tools such as HASSET (Sobradelo et al., 2014a) and VORIS 2.0.1 (Felpeto et al., 2007), specifically designed to undertake volcanic hazard assessment based on current knowledge of past eruptive activity and using probabilistic methods and simulation models, allows us to obtain an initial long-term hazard assessment, which can be easily updated and improved with the incorporation of new information such as a more complete volcanostratigraphy and geochronology. This is an essential tool that should enable local authorities to apply more rational territorial planning and to design more adequate emergency plans to face future volcanic crises. The experience gained from the last eruption on El Hierro in 2011-2012 showed that the lack of tools such as the one described in the present study can lead scientific advisors and decision-makers to consider possible eruptive scenarios that have a very low probability of occurrence, whilst ignoring others with a high probability of occurrence - for example, the submarine eruption that in the end turned out to be the true scenario. This lack of any systematic study of past eruptive activity hampered the forecasting of the most probable scenarios and led to a certain confusion regarding the potential outcome of the impending eruption. This in turn affected the way in which information was transmitted to the population and to the scale of the decisions made, some of which were unnecessarily overprotective (Sobradelo et al., 2014b).

The advantage of conducting a probabilistic hazard assessment is that the results obtained can be updated whenever new information becomes available. Such an approach permits work to start even when only a little information exists and then enables results to improve over time. Thus, appropriate mitigation policies can be based on less, but more precise and realistic information. In the case of El Hierro, despite sufficient knowledge of past eruptive activity, the available information was not structured in a comprehensive way that was easy to manage and be used by decision-makers or even by the scientists who were providing advice. The results obtained in the present study, that is, the development of a probabilistic long-term volcanic hazard assessment that includes dynamic scenarios and a qualitative hazard map (Fig. 7a and b), offer basis on which to build the strategies that are required to successfully face up to and minimise the impact of future volcanic eruptions on the island.

Our approach offers a method that facilitates accomplishing volcanic hazard assessment in a homogeneous and systematic way. The approach is based on the history of the volcano being deduced from the geological record, which allows determining how, where, and when the next eruption could be. Similar approaches have been applied in other volcanic areas where the application of available tools similar to ours have also allowed us to obtain an initial long-term hazard assessment. This is the case of Auckland Volcanic Field in New Zealand (Sandri et al., 2012) or Misti volcano in Peru (Sandri et al., 2014), where a Bayesian approach using BET_VH tool (Marzocchi et al., 2010) and other simulation tools are applied to compute the temporal and spatial probabilities. Our methodology uses different free tools that have been developed to contribute to the long-term hazard assessment, both in spatial (VORIS 2.0.1, Felpeto et al., 2007) and temporal analyses (HASSET, Sobradelo et al., 2014a). The main advantage of using VORIS 2.0.1 is that it creates scenarios of different kind of hazards such as lava flows, PDCs and ashfall. Other works have focused on the simulation of only one scenario using non-free tools (e.g. lava flows for Etna volcano: Cappello et al., 2010, 2011; Tarquini and Favalli, 2010). On the other hand, although some parts of the HASSET tool (that evaluate temporal probabilities) coincide with BET_EF and BET_VH tools presented by Marzocchi et al. (2008, 2010), HASSET is built on a Quantum Gis (QGIS) platform and considers different kinds of unrest episodes (seismic, geothermal, others), and moreover takes into account the kind of outcome (e.g. phreatic explosion and sector failure) and the magma composition, overcoming the limitations of previous event tree models (Sobradelo et al., 2014a). Another important advantage of using these tools is that new data or new model results can be easily included in the procedure to update the hazard assessment. Other works focused on the evaluation of the potential hazards related to a specific kind of hazard of a particular area (e.g. phreatomagmatic volcanic hazards; Németh and Cronin, 2011) could take the advantages of our methodology and implement it in an easy and successful way for future and completeness of volcanic hazard evaluation. 
Acknowledgements. This research was partially funded by IGME, CSIC and the European Commission (FT7 Theme: ENV.2011.1.3.3-1; Grant 282759: "VUELCO"), and MINECO grant CGL2011-16144-E. We would like to thank X. Bolós and J. P. Galve for their help in the development of figures. We also want to thank J. Lindlay and K. Németh for their very useful suggestions that have enabled us to significantly improve our manuscript. The English text was corrected by Michael Lockwood.

Edited by: A. Costa

Reviewed by: J. Lindsay and K. Németh

\section{References}

Alcorn, R., Panter, K. S., and Gorsevski, P. V.: A GIS-based volcanic hazard and risk assessment of eruptions sourced within Valles Caldera, New Mexico, J. Volcanol. Geoth. Res., 267, 114, 2013.

Anguita, F. and Hernán, F.: A propagating fracture model versus a hot spot origin for the Canary Islands, Earth Planet. Sc. Lett., 27, 11-19, 1975.

Anguita, F. and Hernán, F.: The Canary Islands origin: a unifying model, J. Volcanol. Geoth. Res., 103, 1-26, 2000.

Araña, V. and Ortiz, R.: The Canary Islands: Tectonics, magmatism, and geodynamic framework, in: Magmatism in Extensional Structural Settings and the Phanerozoic African Plate, edited by: Kampunzu, A. and Lubala, R., Springer, New York, 209-249, 1991.

Araña, V., Felpeto, A., Astiz, M., García, A., Ortiz, R., and Abella, R.: Zonation of the main volcanic hazards (lava flows and ash fall) in Tenerife, Canary Islands. A proposal for a surveillance network, J. Volcanol. Geoth. Res., 103, 377-391, 2000.

Arrighi, S., Principe, C., and Rosi, M.: Violent Strombolian and subplinian eruptions at Vesuvius during post-1631 activity, Bull. Volcanol., 63, 126-150, 2001.

Balcells, R. and Gómez, J. A.: Memorias y mapas geológicos del Plan MAGNA a escala 1:25.000 de las Hojas correspondientes a la isla de El Hierro, Geol. Surv. of Spain, Madrid, 1997.

Bartolini, S., Cappello, A., Martí, J., and Del Negro, C.: QVAST: a new Quantum GIS plugin for estimating volcanic susceptibility, Nat. Hazards Earth Syst. Sci., 13, 3031-3042, doi:10.5194/nhess-13-3031-2013, 2013.

Bebbington, M. and Cronin, S. J.: Spatio-temporal hazard estimation in the Auckland Volcanic Field, New Zealand, with a new event-order model, Bull. Volcanol., 73, 55-72, 2011.

Becerril, L.: Approach to volcanic hazard and its effects in coastal areas of the Canary Islands, Master's thesis, Universidad de Las Palmas de Gran Canaria, Las Palmas, Spain, available on line at: http://hdl.handle.net/10553/4595, 2009.

Becerril, L., Cappello, A., Galindo, I., Neri, M., and Del Negro, C.: Spatial probability distribution of future volcanic eruptions at El Hierro Island (Canary Islands, Spain), J. Volcanol. Geoth. Res., 257, 21-30, doi:10.1016/j.jvolgeores.2013.03.005, 2013.

Bolós, X., Planagumà, L., and Martí, J.: Volcanic stratigraphy of the Quaternary La Garrotxa Volcanic Field (NE Iberian Peninsula), J. Quaternary. Sci., in press, 2014.
Cappello A., Del Negro C. and Vicari A.: Lava flow susceptibility map of Mt Etna based on numerical simulations, in: From Physics to Control through an Emergent View, World Sci. Ser. Nonlin. Sci. B, 5, 201-206, 2010.

Cappello, A., Vicari, A. M., and Del Negro, C.: Assessment and modeling of lava flow hazard on Mt. Etna volcano, B. Geofis. Teor. Appl., 52, 299-308, 2011.

Cappello, A., Neri, M., Acocella, V., Gallo, G., Vicari, A., and Del Negro, C.: Spatial vent opening probability map of Mt Etna volcano (Sicily, Italy), Bull. Volcanol., 74, 2083-2094, 2012.

Cappello, A., Bilotta, G., Neri, M., and Del Negro, C.: Probabilistic modeling of future volcanic eruptions at Mount Etna, J. Geophys. Res., 118, 1925-1935, doi:10.1002/jgrb.50190, 2013.

Carracedo, J. C., Day, S., Guillou, H., Rodríguez Badiola, E., Canas, J. A., and Pérez-Torrado, F. J.: Hotspot volcanism close to a passive continental margin: the Canary Islands, Geol. Mag., 135, 591-604, 1998.

Carracedo, J. C., Rodríguez Badiola, E., Guillou, H., de La Nuez, H. J., and Pérez Torrado, F. J.: Geology and Volcanology of the Western Canaries: La Palma and El Hierro, Estud. Geol. 57, 171295, 2001.

Carracedo, J. C., Guillou, H., Paterne, M., Scaillet, S., Rodríguez Badiola, E., Paris, R., Pérez Torrado, F. J., and Hansen Machín, A.: Análisis del riesgo volcánico asociado al flujo de lavas en Tenerife (Islas Canarias): escenarios previsibles para una futura erupción en la isla, Estud. Geol., 60, 63-93, 2004a.

Carracedo, J. C., Guillou, H., Paterne, M., Scaillet, S., Rodríguez Badiola, E., Paris, R., Pérez Torrado, F. J., and Hansen, A.: Avance de un mapa de peligrosidad volcánica de Tenerife (escenarios previsibles para una futura erupción en la isla), Servicio de Publicaciones de la Caja General de Ahorros de Canarias (CajaCanarias), Tenerife, 46 pp., 2004b.

Carracedo, J. C., Pérez Torrado, F. J., Rodríguez Badiola, E., Hansen, A., Paris, R., Guillou, H., and Scaillet, S.: Análisis de los riesgos geológicos en el Archipiélago Canario: Origen, características, probabilidades y tratamiento, Anuario de Estudios Atlánticos, 51, 513-574, 2005.

Chester, D. K., Dibbenb, C. J. L., and Duncanc, A. M.: Volcanic hazard assessment in western Europe, J. Volcanol. Geoth. Res., 115, 411-435, 2002.

Connor, C. B. and Connor, L. J.: Estimating spatial density with kernel methods, in: Volcanic and Tectonic Hazard Assessment for Nuclear Facilities, edited by: Connor, C. B., Chapman, N. A., Connor, L. J., Cambridge University Press, 346-368, 2009.

Crisci, G. M., Iovine, G., Di Gregorio. S., and Lupiano, V.: Lavaflow hazard on the SE flank of Mt. Etna (Southern Italy), J. Volcanol. Geoth. Res., 177, 778-796, 2008.

Felpeto, A.: Modelización física y simulación numérica de procesos eruptivos para la generación de mapas de peligrosidad volcánica, Ph.D. thesis, University of Madrid, Madrid, Spain, 250 pp., 2002.

Felpeto, A., Araña, V., Ortiz, R., Astiz, M., and García, A.: Assessment and modelling of lava flow hazard on Lanzarote (Canary Islands), Nat. Hazards, 23, 247-257, 2001.

Felpeto, A., Martí, J., and Ortiz, R.: Automatic GIS-based system for volcanic hazard assessment, J. Volcanol. Geoth. Res., 166, 106-116, doi:10.1016/j.jvolgeores.2007.07.008, 2007.

Fournier d'Albe, E. M.: Objectives of volcanic monitoring and prediction, J. Geol. Soc. Lond., 136, 321-326, 1979. 
Fúster, J. M., Hernán, F., Cendrero, A., Coello, J., Cantangrel, J. M., Ancochea, E., and Ibarrola, E.: Geocronología de la isla de El Hierro (Islas Canarias), Boletín de la Real Sociedad Española de Historia Natural, (Geología), 88, 86-97, 1993.

Gee, M. J. R., Masson, D. G., Watts, A. B., and Mitchell, N. C.: Offshore continuation of volcanic rift zones, El Hierro, Canary Islands, J. Volcanol. Geoth. Res., 105, 107-119, doi:10.1016/S0377-0273(00)00241-9, 2001.

Gómez-Fernández, F.: Desarrollo de una Metodología para el Análisis del Riesgo Volcánico en el marco de un Sistema de Información Geográfica, Ph.D. thesis, University of Madrid, Madrid, Spain, 255 pp., 1996.

Guillou, H., Carracedo, J. C., Pérez-Torrado, F. J., and Rodríguez Badiola, E.: K-Ar ages and magnetic stratigraphy of a hotspotinduced, fast grown oceanic island: El Hierro, Canary Islands, J. Volcanol. Geoth. Res. 73, 141-155, 1996.

Hernández Pacheco, A.: Sobre una posible erupción en 1793 en la Isla del Hierro (Canarias), Estud. Geol., 38, 15-25, 1982.

Hill, D. P., Dzurisin, D., Ellsworth, W. L., Endo, E. T., Galloway, D. L., Gerlach, T. M., Johnston, M. S. J., Langbein, J., McGee, K. A., Miller, C. D., Oppenheimer, D., and Sorey, M. L.: Response plan for volcano hazards in the Long Valley Caldera and Mono craters region California, Bull. Geol. Surv., 65, 2185, 2001.

Hoernle, K. and Schmincke, H. U.: The role of partial melting in the 15 Ma geochemical evolution of Gran Canaria: a blob model for the Canary hotspot, J. Petrol., 34, 599-626, 1993.

Hoernle, K., Zhang, Y. S., and Graham, D.: Seismic and geochemical evidence for large-scale mantle upwelling beneath the eastern Atlantic and western and central Europe, Nature, 374, 34-39, 1995.

Kereszturi, G. and Németh, K.: Monogenetic Basaltic Volcanoes: Genetic Classification, Growth, Geomorphology and Degradation, in: Updates in Volcanology-New Advances in Understanding Volcanic Systems, edited by: Németh, K., InTech, 3-88, doi:10.5772/51387, 2012.

Kereszturi, G., Németh, K., Cronin, S. J., Agustín-Flores, J., Smith I. E. M., and Lindsay, J.: A model for calculating eruptive volumes for monogenetic volcanoes - Implication for the Quatemary Auckland Volcanic Field, New Zealand, J. Volcanol. Geoth. Res., 266, 16-33, 2013.

Kilburn, C. R. J.: Multiscale fracturing as a key to forecasting volcanic eruptions, J. Volcanol. Geoth. Res., 125, 271-289, 2003.

Klügel, A., Hansteen, T. H., van den Bogaard, P., Strauss, H., and Hauff, F.: Holocene fluid venting at an extinct Cretaceous seamount, Canary archipelago, Geology, 39, 855-858, 2011.

Le Bas, M. J., Rex, D. C., and Stillmann, C. J.: The early magmatic chronology of Fuerteventura, Canary Islands, Geol. Mag., 123, 287-298, 1986.

Le-Pichon, X. and Fox, P. J.: Marginal offsets, fracture zones, and the early opening of the North Atlantic, J. Geophys. Res., 76, 2156-2202, doi:10.1029/JB076i026p06294, 1971.

Lindsay, J. M., Robertson, R., Shepherd, J., and Ali, S.: Volcanic Hazard Atlas of the Lesser Antilles, Trinidad and Tobago, The Seismic Research Unit, University of the West Indies, Trinidad and Tobago, 1-47, 2005.

Lirer, L., Petrosino, P., and Alberico, I.: Volcanic hazard assessment at volcanic fields: the Campi Flegrei case history, J. Volcanol. Geoth. Res., 101, 55-75, 2001.
Longpré, M. A., Chadwick, J. P., Wijbrans, J., and Iping, R.: Age of the El Golfo debris avalanche, El Hierro (Canary Islands): New constraints from laser and furnace ${ }^{40} \mathrm{Ar} /{ }^{39} \mathrm{Ar}$ dating, J. Volcanol. Geoth. Res., 203, 76-80, 2011.

López, C., Blanco, M. J., Abella, R., Brenes, B., CabreraRodríguez, V. M., Casas, B., Domínguez-Cerdeña, I., Felpeto, A., Fernández de Villalta, M., Del Fresno, C., García, O., GarcíaArias, M. J., García-Canada, L., Gomis-Moreno, A., GonzálezAlonso, E., Guzmán-Pérez, J., Iribarren, I., López-Díaz, R., Luengo-Oroz, N., Meletlidis, S., Moreno, M., Moure, D., Pereda de Pablo, J., Rodero, C., Romero, E., Sainz-Maza, S., SentreDomingo, M. A., Torres, P. A., Trigo, P., and Villasante-Marcos, M.: Monitoring the unrest of El Hierro (Canary Islands) before the onset of the 2011 Submarine Eruption, Geophys. Res. Lett., 39, L13303, doi:10.1029/2012GL051846, 2012.

Marinoni, L. B. and Pasquaré, G.: Tectonic evolution of the emergent part of a volcanic ocean island: Lanzarote, Canary Islands, Tectonophysics, 239, 111-137, doi:10.1016/00401951(94)90110-4, 1994.

Martí, J. and Felpeto, A.: Methodology for the computation of volcanic susceptibility. An example for mafic and felsic eruptions on Tenerife (Canary Islands), J. Volcanol. Geoth. Res. 195, 69-77, doi:10.1016/j.jvolgeores.2010.06.008, 2010.

Martí, J., Sobradelo, R., Felpeto, A., and García, O.: Eruptive scenarios of phonolitic volcanism at Teide-Pico Viejo volcanic complex (Tenerife, Canary Islands), Bull. Volcanol., 74, 767-782, doi:10.1007/s00445-011-0569-6, 2012.

Martí, J., Pinel, V., López, C., Geyer, A., Abella, R., Tárraga, M., Blanco, M. J., Castro, A., and Rodríguez, C.: Causes and mechanisms of El Hierro submarine eruption (2011-2012) (Canary Islands), J. Geophys. Res., 118, 1-17, doi:10.1002/jgrb.50087, 2013.

Martin, A. J., Umeda, K., Connor, C. B., Weller, J. N., Zhao, D., and Takahashi, M.: Modeling long-term volcanic hazards through Bayesian inference: an example from the Tohuku volcanic arc Japan, J. Geophys. Res., 109, B10208, doi:10.1029/2004JB003201, 2004.

Marzocchi, W., Sandri, L., and Furlan, C.: A quantitative model for volcanic hazard assessment, in: Statistics in Volcanology, edited by: Mader, H. M., Coles, S. G., Connor, C. B., and Connor, L. J., Special Publication of IAVCEI, Geological Society of London, London, 2006.

Marzocchi, W., Sandri, L., and Selva, J.: BET_EF: A probabilistic tool for long- and short-term eruption forecasting, Bull. Volcanol., 70, 623-632, doi:10.1007/s00445-007-0157-y, 2008.

Marzocchi, W., Sandri, L., and Selva, J.: BET_VH: a probabilistic tool for long-term volcanic hazard assessment, Bull. Volcanol., 72, 705-716, 2010.

Németh, K.: Monogenetic Volcanic Fields: Origin, Sedimentary Record, and Relationship with Polygenetic Volcanism, in: What Is a Volcano? Gsa Special Papers Volume 470, edited by: CañónTapia, E. and Szakács, A., Geological Society of America, Boulder, Colorado, 43-67, 2010.

Németh, K. and Cronin, S. J.: Drivers of explosivity and elevated hazard in basaltic fissure eruptions: The 1913 eruption of Ambrym Volcano, Vanuatu (SW-Pacific), J. Volcanol. Geoth. Res., 201, 194-209, 2011. 
Newhall, C. G. and Hoblitt, R. P.: Constructing event trees for volcanic crisis, Bull. Volcanol., 64, 3-20, doi:10.1007/s004450100173, 2002.

Newhall, G. G. and Self, S.: The Volcanic Explosivity Index (VEI): An estimate of explosive magnitude of historic eruptions, J. Volcanol. Geoth. Res., 87, 1231-1238, 1982.

Pareschi, M. T., Cavarra, L., Favalli, M., Giannini, F., and Meriggi, A.: GIS and Volcanic Risk Management, Nat. Hazards, 21, 361379, 2000.

Pedrazzi, D., Becerril, L., Martí, J., Meletlidis, S., and Galindo, I.: Explosive felsic volcanism on El Hierro (Canary Islands), Bull. Volcanol., in press, 2014.

Pellicer, M. J.: Estudio volcanológico de la isla de El Hierro (Islas Canarias), Estud. Geol., 33, 181-197, 1977.

Pellicer, M. J.: Estudio geoquímico del vulcanismo de la isla de Hierro, Archipiélago Canario, Estud. Geol., 35, 15-29, 1979.

Pérez-Torrado, F. J., Rodríguez-González, A., Carracedo, J. C., Fernández-Turiel, J. L., Guillou, H., Hansen, A., and Rodríguez Badiola, E.: Edades C-14 Del Rift ONO de El Hierro (Islas Canarias), in: El Cuaternario en España y Áreas Afines, Avances en 2011, edited by: Turu, V. and Constante, A., Asociación Española para el Estudio del Cuaternario (AEQUA), Andorra, 101104, 2011.

Pérez-Torrado, F. J., Carracedo, J. C., Rodríguez-González, A., Soler, V., Troll, V. R., and Wiesmaier, S.: La erupción submarina de La Restinga en la isla de El Hierro, Canarias: Octubre 2011-Marzo 2012, Estud. Geol., 68, 5-27, doi:10.3989/egeol.40918.179, 2012.

Pfeiffer, T., Costa, A., and Macedonio, G.: A model for the numerical simulation of tephra fall deposits, J. Volcanol. Geoth. Res., 140, 273-294, 2005.

Phillipson, G., Sobradelo, R., and Gottsmann, J.: Global volcanic unrest in the $21^{\text {st }}$ century: An analysis of the first decade, J. Volcanol. Geoth. Res., 264, 183-196, 2013.

Rivera, J., Lastras, G., Canals, M., Acosta, J., Arrese, B., Hermida, N., Micallef, A., Tello, O., and Amblas, D.: Construction of an oceanic island: Insights from the El Hierro (Canary Islands) 2011-2012 submarine volcanic eruption, Geology, 41, 355-358, doi:10.1130/G33863.1, 2013.

Robertson, A. H. F. and Stillman, C. J.: Submarine volcanic and associate sedimentary rocks of the Fuerteventura Basal Complex, Canary Islands, Geol. Mag., 116, 203-214, 1979.

Rodríguez-González, A.: El Vulcanismo Holoceno de Gran Canaria: Aplicación de un sistema de Información Geográfica, Ph.D. thesis, University of Las Palmas de Gran Canaria, Las Palmas de Gran Canaria, Spain, 424 pp., 2009.

Rodríguez-González, A., Pérez-Torrado, F. J., Fernandez-Turiel, J. L., Carracedo, J. C., and Guillou, H.: GIS-based geomorphological modeling of coastal platform-forming eruptions: Montaña del Tesoro volcano (El Hierro, Canary Islands), Geotemas, Sociedad Geológica de Madrid, Madrid, 13 pp., 2012.

Sandri, L., Jolly, G., Lindsay, J., Howe, T., and Marzocchi, W.: Combining long- and short-term probabilistic volcanic hazard assessment with cost-benefit analysis to support decision making in a volcanic crisis from the Auckland Volcanic Field, New Zealand, Bull. Volcanol., 74, 705-723, 2012.
Sandri, L., Thouret, J. C., Constantinescu, R., Biass, S., and Tonini, R.: Long-term multi-hazard assessment for El Misti volcano (Peru), Bull. Volcanol., 76, 771-797, doi:10.1007/s00445-0130771-9, 2014.

Schmincke, H. U.: Volcanic and chemical evolution of the Canary Islands, in: Geology of the Northwest African continental margin, edited by: von Rad, U., Hinz, K., Sarnthein, M., and Seibold, E., Springer, Berlin, Heidelberg, New York, 273-306, 1982.

Schmincke, H. U. and Sumita, M.: Geological Evolution of the Canary Islands. Görres-Verlag, Koblenz, Germany, p. 200, 2010.

Self, S.: The Recent volcanology of Terceira, Azores, J. Geol. Soc. Lond., 132, 645-666, 1976.

Sheridan, M. F. and Malin, M. C.: Application of computer-assisted mapping to volcanic hazard evaluation of surge eruption: Vulcano, Lipari, Vesuvius. Explosive Volcanism, J. Volcanol. Geoth. Res., 17, 187-202, 1983.

Sobradelo, R. and Martí, J.: Bayesian event tree for long-term volcanic hazard assessment: Application to Teide-Pico Viejo stratovolcanoes, Tenerife, Canary Islands, J. Geophys. Res., 115, B05206, doi:10.1029/2009JB006566, 2010.

Sobradelo, R., Martí, J., Mendoza-Rosas, A. T., and Gómez, G.: Volcanic hazard assessment for the Canary Islands (Spain) using extreme value theory, Nat. Hazards Earth Syst. Sci., 11, 27412753, doi:10.5194/nhess-11-2741-2011, 2011.

Sobradelo, R., Bartolini, S., and Martí, J.: HASSET: a probability event tree tool to valuate future volcanic scenarios using Bayesian inference Presented as a plugin for QGIS, Bull. Volcanol., 76, 770-785, doi:10.1007/s00445-013-0770-x, 2014a.

Sobradelo, R., Martí, J., Kilburn, C., and López, C.: Probabilistic approach to decision making under uncertainty during volcanic crises, Nat. Hazards, submitted, 2014b.

Stroncik, N. A., Klügel, A., and Hansteen, T. H.: The magmatic plumbing system beneath El Hierro (Canary Islands): constraints from phenocrysts and naturally quenched basaltic glasses in submarine rocks, Contrib. Mineral. Petrol., 157, 593-607, 2009.

Széréméta, N., Laj, C., Guillout, H., Kissel, C., Mazaud, A., and Carracedo, J. C.: Geomagnetic paleosecular variation in the Brunhes period, from the island of El Hierro (Canary Islands), Earth Planet. Sc. Lett., 165, 241-253, 1999.

Tarquini, S. and Favalli, M.: Changes of the susceptibility to lava flow invasion induced by morphological modifications of an active volcano: the case of Mount Etna, Italy, Nat. Hazards, 54, 537-546, 2010.

Toyos, G. P., Cole, P. D., Felpeto, A., and Martí, J.: A GIS-based methodology for hazard mapping of small pyroclastic density currents, Nat. Hazards, 41, 99-112, 2007.

Valentine, G. A.: Eruption column physics, in: From Magma to Tephra - Modelling Physical Processes of Explosive Volcanic Eruptions, edited by: Freundt, A., Rosi, M., Elsevier, Amsterdam, 91-138, 1998.

Valentine, G. A. and Gregg, T. K. P.: Continental basaltic volcanoes - processes and problems, J. Volcanol. Geotherm. Res., 177, 857-873, 2008.

Van der Bogard, P.: The origin of the Canary Island Seamount Province-New ages of old seamounts, Scientific Rep., 3, 1-7, 2013. 
Vicari, A., Bilotta, G., Bonfiglio, S., Cappello, A., Ganci, G., Hérault, A., Rustico, E., Gallo, G., and Del Negro, C.: LAV@HAZARD: a web-GIS interface for volcanic hazard assessment, Ann. Geophys.-Italy, 54, 662-670, 2011.
Voight, B. and Cornelius, R. R.: Prospects for eruption prediction in near-real-time, Nature, 350, 695-698, 1991. 